\title{
Environmental flows in the Rio Grande - Rio Bravo basin
}

\author{
$\underline{\text { Samuel Sandoval-Solis }}^{1,2}, \underline{\text { Stephanie Paladino }}^{3}, \underline{\text { Laura E. Garza-Diaz }}^{4}, \underline{\text { Luzma F. Nava }}^{5,6}, \underline{\text { Jack R. Friedman }}^{7}, \underline{\text { J. Pablo Ortiz-Partida }}^{14}$ \\ ${ }^{8}$, Sophie Plassin ${ }^{9,10}$, Grace Gomez-Quiroga ${ }^{11}$, Jennifer Koch ${ }^{9,12}$, Jeri Fleming ${ }^{13}$, Belize A. Lane ${ }^{14}$, Sean Wineland ${ }^{9}$, Ali Mirchi ${ }^{15}$, \\ Ramon Saiz-Rodriguez $^{4}$ and Thomas M. Neeson ${ }^{9}$
}

\begin{abstract}
The Rio Grande/Bravo is an arid river basin shared by the United States and Mexico, the fifth-longest river in North America, and home to more than 10.4 million people. By crossing landscapes and political boundaries, the Rio Grande/Bravo brings together cultures, societies, ecosystems, and economies, thereby forming a complex social-ecological system. The Rio Grande/Bravo supplies water for the human activities that take place within its territory. While there have been efforts to implement environmental flows (flows necessary to sustain riparian and aquatic ecosystems and human activities), a systematic and whole-basin analysis of these efforts that conceptualizes the Rio Grande/Bravo as a single, complex social-ecological system is missing. Our objective is to address this research and policy gap and shed light on challenges, opportunities, and success stories for implementing environmental flows in the Rio Grande/Bravo. We introduce the physical characteristics of the basin and summarize the environmental flows studies already done. We also describe its water governance framework and argue it is a distributed and nested governance system across multiple political jurisdictions and spatial scales. We describe the environmental flows legal framework and argue that the authority over different aspects of environmental flows is divided across different agencies and institutions. We discuss the prioritization of agricultural use within the governance structure without significant provisions for environmental flows. We introduce success stories for implementing environmental flows that include leasing of water rights or voluntary releases for environmental flow purposes, municipal ordinances to secure water for environmental flows, nongovernmental organizations representing the environment in decision-making processes, and acquiring water rights for environmental flows, among others initiatives. We conclude that environmental flows are possible and have been implemented but their implementation has not been systematic and permanent. There is an emerging whole-basin thinking among scientists, managers, and citizens that is helping find common-ground solutions to implementing environmental flows in the Rio Grande/Bravo basin.
\end{abstract}

Key Words: environmental flows, Rio Bravo, Rio Grande, social-ecological systems, transboundary basins

\section{INTRODUCTION}

\section{The Rio Grande/Río Bravo as a social-ecological system}

Overview

The Rio Grande/Bravo is a transboundary river basin shared by the United States and Mexico, and is home to more than 10.4 million people. It is the fifth longest river in North America, with a length of approximately $3000 \mathrm{~km}$, two-thirds of which delimit the border between the two countries (Fig. 1). The Rio Grande/ Bravo has a drainage area of approximately $557,000 \mathrm{~km}^{2}$ and extends over three states in the United States (Colorado, New Mexico, and Texas) and five states in Mexico (Durango, Chihuahua, Coahuila, Nuevo León, and Tamaulipas).

The Rio Grande/Bravo as a social-ecological system By crossing landscapes and political boundaries, the Rio Grande/ Bravo brings together cultures, societies, ecosystems, and economies, thereby forming a complex social-ecological system (SES) (Koch et al. 2019, Plassin et al. 2020). Understanding the relationships and feedback between people and water is a prerequisite to understanding the long-term dynamics of a region's hydrology (Sivapalan et al. 2011). According to Ostrom
(2009), all resources used by humans, including water, are intrinsic components of SESs. Finding sustainable solutions for the use of these resources requires the identification and analysis of the relationships between different social and ecological components of SESs across spatial and temporal scales (Ostrom 2009). The Rio Grande/Bravo is an arid, water-limited, and drought-prone basin that supplies water for all the economic activities that take place within its territory. However, environmental flows - stream flows necessary to sustain aquatic ecosystems, which in turn support human cultures, economies, sustainable livelihoods, and well-being (Arthington et al. 2018) - have not been addressed within the water governance and allocation institutions of the basin (Nava et al. 2016), similar to other water-scarce areas (King and Brown 2006). We examine environmental flows within the context of the Rio Grande/Bravo as a complex SES, where it is not possible to decouple the social, political, economic, hydrological, and ecological aspects from each other. Approaching the Rio Grande/Bravo basin as an SES allows the framing of challenges and opportunities for implementing environmental flows in ways that are not only technically and legally sound and socially needed, but necessary to sustain ecosystem functions and the ecological goods and services

${ }^{1}$ Department of Land, Air, and Water Resources, University of California, Davis, USA., ${ }^{2}$ Division of Agriculture and Natural Resources, University of California, Davis, USA., ${ }^{3}$ MeroLek Anthropology, ${ }^{4}$ Hydrologic Sciences Graduate Group, University of California, Davis, USA, ${ }^{5}$ CONACYT, Centro del Cambio Global y la Sustentabilidad A. C., Mexico, ${ }^{6}$ International Institute for Applied Systems Analysis (IIASA), Austria, ${ }^{7} \mathrm{Center}$ for Applied Social Research, University of Oklahoma, USA, ${ }^{8}$ Climate and Energy, Union of Concerned Scientists, USA, ${ }^{9}$ Department of Geography and Environmental Sustainability, University of Oklahoma, USA, ${ }^{10}$ AGIR, Univ Toulouse, INRAE, Castanet-Tolosan, France, ${ }^{11}$ University of California, Davis, USA, ${ }^{12}$ Data Institute for Societal Challenges, University of Oklahoma, USA, ${ }^{13}$ Grand River Dam Authority, USA, ${ }^{14}$ Department of Civil and Environmental Engineering, Utah State University, USA, ${ }^{15}$ Department of Biosystems and Agricultural Engineering, Oklahoma State University, USA 
Fig. 1. Main rivers, reservoirs, cities, and population settlements in the Rio Grande/Bravo basin.

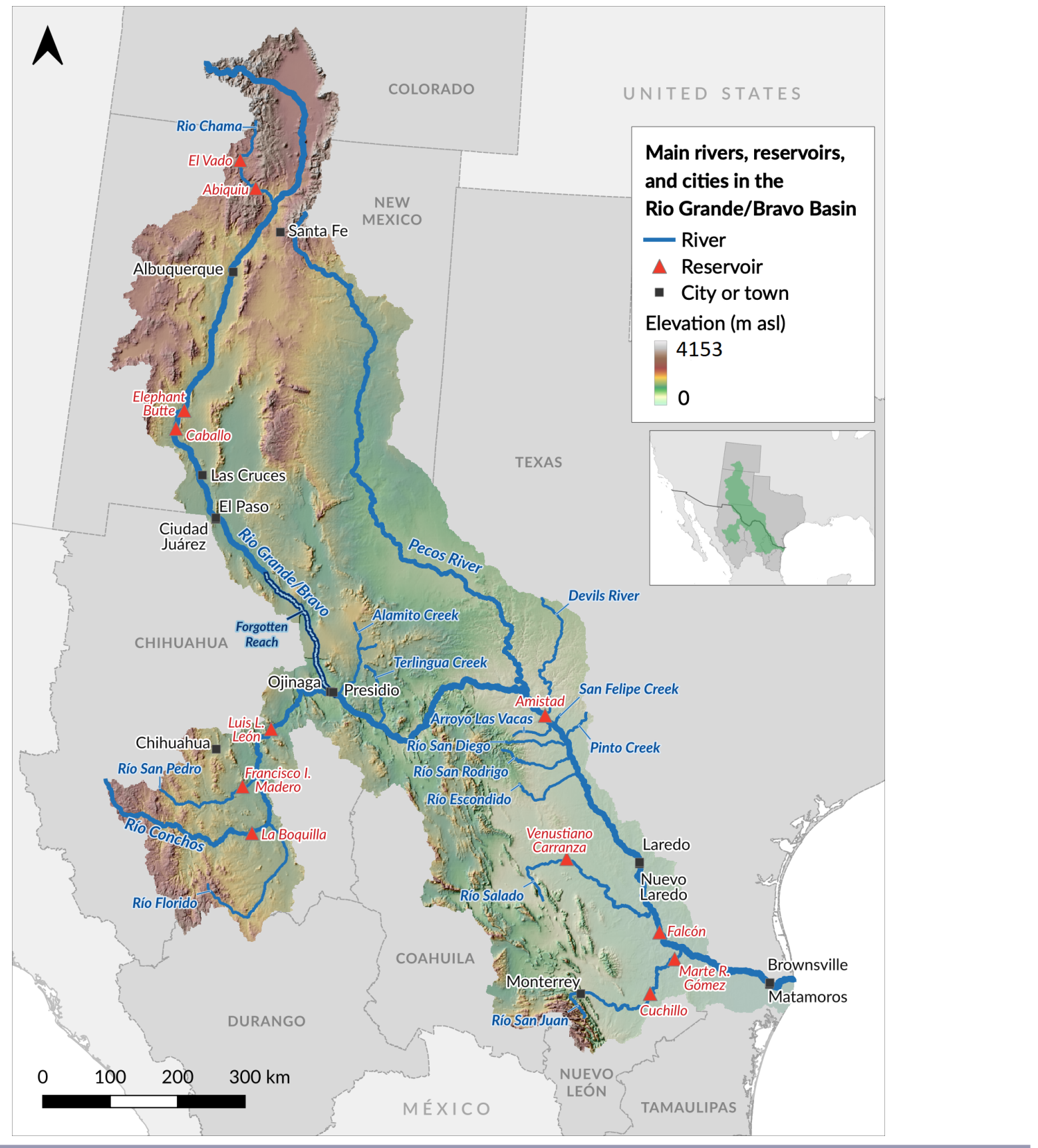

provided to people (Balvanera et al. 2006). Through this exercise, we highlight some of the key socio-political-legal challenges to integrating environmental flows into existing water governance and management practices within the Rio Grande/Bravo. We then describe several initiatives that represent innovative attempts to implement environmental flows within this challenging context. We recognize the Rio Grande/Bravo as a basin with shared common-pool resources; therefore, managing common-pool resources in a transboundary SES requires understanding both natural and social systems.
River degradation

Since the 1870s, the Rio Grande/Bravo basin has experienced a long history of human manipulation (Enríquez Coyro 1976, Horgan 1984). Economic and agricultural development has resulted in severe impacts on river ecosystems, and hydraulic infrastructure has considerably altered the basin's natural flow regime (Blythe and Schmidt 2018). The extent of environmental degradation can be seen most drastically along a $240-\mathrm{km}$ stretch of the river, often referred to as the Forgotten Reach (Fig. 1), which at times is completely dry due to upstream diversions 
(Everitt 1993, Kelly and Arias Rojo 2007, Blythe 2018). The river corridor itself has also been heavily modified, including the human-engineered straightening of the mainstem in some areas for conveyance and flood protection (e.g., in Presidio/Ojinaga and El Paso/Cd. Juarez), as well as channel narrowing and incision caused by reduced frequency of flood flows and encroachment of invasive vegetation (e.g., in the Big Bend Reach). These physical changes make it harder for the river to access its floodplains, which reduces the availability of shallow and low-velocity spawning habitat (the preferred conditions for the endangered Rio Grande silvery minnow [Hybognathus amarus] [USFWS 2010]) and promotes recruitment of invasive species (e.g., Tamarix spp. and Arundo donax). Furthermore, the basin is experiencing increasing threats due to climate change (Hurd and Coonrod 2012, Elias et al. 2015) that are affecting water availability (Utton 1999, Kelly 2002), changing the timing and volume of snowmelt in the basin's headwaters (Rango 2006), and increasing the frequency of tropical storm events in tributaries, such as the Rio Conchos (Sayto-Corona et al. 2017). Environmental flows need to be provided to maintain both river ecosystems and water provision for human needs. While there have been recent efforts to implement environmental flow agreements at various locations throughout the basin, a systematic and integrated analysis of these efforts that conceptualizes the whole Rio Grande/Bravo as a complex social-ecological system is missing.

Our objective is to address this research and policy gap and shed light on challenges, opportunities, and success stories for implementing environmental flows in the Rio Grande/Bravo. Our methodology combines a literature review with the bilingual, multidisciplinary, and topical expertise of the authors, which includes social, political, legal, environmental, and hydrological research in the basin. We focused on three questions: (1) What is the current status of knowledge about environmental flows and their relation to ecosystem and human water needs in the Rio Grande/Bravo? (2) In what ways do current water governance frameworks in the basin appear to support or hinder the establishment of environmental flows? (3) Are there policies or practices that have implemented environmental flows, and what lessons can be learned from those experiences for a more widespread implementation in the basin? We address these questions by considering the Rio Grande/Bravo as a whole basin. The target audience for this research study is scientists, natural resources managers, decision-makers, and land, water, and environmental advocates who are interested in better understanding both technical and socio-political conditions for integrating environmental flows into existing water governance and management practices. While the focus is the Rio Grande/ Bravo, we believe there are many dynamics represented that are relevant to other areas of the North American arid west, as well as to arid lands elsewhere. Fig. 2 provides an overview of the topics discussed in this research study. We have created a repository of the geographic information presented in this study (SandovalSolis and Lane 2021).

\section{Basin characteristics}

The Rio Grande/Bravo's biological richness is embodied in the basin's diverse topography (with elevations ranging from sea level to $4365 \mathrm{~m}$ ), climatology (snow- and hurricane-driven precipitation ranging from 190 to $2260 \mathrm{~mm} /$ year), hydrology (including diverse streamflow regimes), and ecoregions (crossing five continental ecoregions). These characteristics shape a diverse environment with climatic and hydrologic contrasts, from high mountain terrain to desert landscapes, river canyons, and a wide deltaic floodplain, which results in exceptionally high diversity of plant and animal life. The climatic and topographic diversity also affects the flow regime of the Rio Grande/Bravo; its principal streamflow sources are (1) snowmelt from the San Juan Mountains of southern Colorado and the Sierra Tarahumara mountains of northern New Mexico, (2) monsoon-driven flows during the hurricane season from the Pacific and Atlantic Oceans, and (3) groundwater inflow to streams throughout the basin. These streamflow sources shape the features of the Rio Grande/ Bravo's riverine ecosystems and its natural flow regime.

Fig. 2. Overview of the topics discussed.

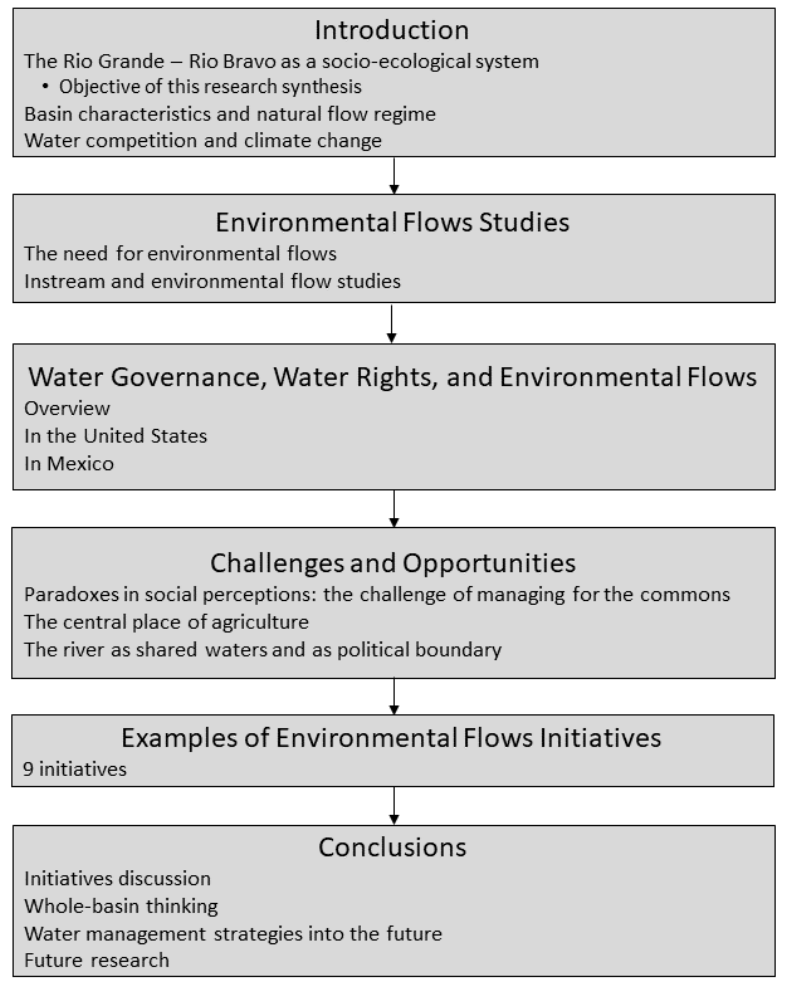

\section{Natural flow regime}

Prior to substantial human impacts on the river, starting in the 1870s, the natural flow regime of the Rio Grande/Bravo evolved along its mainstem. A large spring snowmelt pulse was the dominant signal upstream of Ojinaga/Presidio (Fig. 1) (hereafter referred to as the northern branch [Blythe and Schmidt 2018]), and a bimodal snowmelt and monsoonal rain flow regime occurred downstream of Ojinaga/Presidio (hereafter referred to as the southern branch). In the main tributaries of the southern branch, the flow regime was dominated by a seasonal monsoonal rainfall-driven signal from July to September, and a stable groundwater-fed baseflow during the dry months. Flash floods in small ephemeral tributaries contributed infrequent large flow and sediment pulses (Schmidt et al. 2003, Dean and Schmidt 2013). These distinctive streamflow signatures provided the 
dynamic natural processes that the river ecosystems depend on (Poff et al. 1997). For example, many riparian plant species (e.g., Rio Grande cottonwood) are evolutionarily adapted to germinate after predictable, annual, snowmelt-driven high flows (Bhattacharjee et al. 2009). Flood flows from heavy rains provide migration and spawning cues for native fish such as the Rio Grande cutthroat trout (Oncorhynchus clarkii virginalis) (Young 1995), and restore water quality conditions (Postel et al. 2003). Management, maintenance, and restoration of a healthy river involves more than maintaining a constant minimum flow; it requires maintaining or restoring key aspects of this dynamic flow regime specifically to sustain critical ecological functions while continuing to meet human water management objectives.

\section{Water competition and climate change}

Today, the Rio Grande/Bravo bears little resemblance to its prealtered condition before 1877, when the Desert Land Act was enacted (Scurlock 1998, Wozniak 1998), after which irrigation activities steadily expanded during the 20th century. Increased water use and hydraulic infrastructure (Sandoval-Solis et al. 2011) have significantly altered the natural flow (Gonzalez-Escorcia 2017, Blythe and Schmidt 2018) and sediment regimes (Dean and Schmidt 2011). Agriculture, municipal and domestic uses, industries, hydroelectric power, and recreational activities compete for water. Currently, agriculture accounts for $83 \%$ of water withdrawals in the Rio Grande/Bravo but covers less than $5 \%$ of the basin area (CONAGU 2010, U.S. Geological Survey 2010). In addition, continued water use from growing cities has intensified the pressure on already scarce freshwater resources. Overall, during the latter half of the 20th century and the early 21st century (1950-2010), these water demands have reduced the natural flow of the river by more than $95 \%$ in the Forgotten Reach (Blythe and Schmidt 2018), which has resulted in the Rio Grande/ Bravo being listed among the most at-risk rivers in the world (Wong et al. 2007).

Climate change is already affecting the Rio Grande/Bravo streamflow timing and volume through changes in air temperature, snowfall and snowpack, rainfall, and increased evapotranspiration rates (Llewellyn and Vaddey 2013). The Rio Grande/Bravo basin spans a climatic gradient from semi-arid to subhumid; its environment is vulnerable to extreme hydroclimatic events, especially droughts, which are expected to become more severe in this region by the end of the 21 st century (Cayan et al. 2010, Cook et al. 2015). In contrast, large rain events, influenced by tropical storms and hurricanes that impact the Rio Grande/ Bravo from the Pacific and Atlantic Oceans, have increased in frequency (Sayto-Corona et al. 2017), which is resulting in flooding of human settlements, crop destruction, economic losses, and human fatalities. In fact, streamflow decreased at nine of 12 sites upstream of Albuquerque, New Mexico between 1980 and 2015 (Rumsey et al. 2020). In almost all cases, the decrease was associated with decreases in baseflow and snowmelt rates. Moreover, Lehner et al. (2017) showed that the current decreasing trend in the fraction of runoff produced from precipitation is unprecedented in the last 445 years. Elias et al. (2015) estimated that runoff volume will range from $+7 \%$ to $-18 \%$, and the timing of 7-day peak runoff will range from 14 to 24 days earlier upstream of Albuquerque by the end of the century. Samimi et al. (2020) evaluated the effects of four carbon emission scenarios for water availability upstream of Elephant Butte (Fig. 1); most of the projections showed a declining annual streamflow across all projections (Townsend and Gutzler 2020). Ingol-Blanco and McKinney (2010) projected a streamflow decline in the Río Conchos outlet of $18 \%$ by the end of the century. Changes in air temperature are also expected to exacerbate water quality issues, especially in the border cities of the southern branch (DuranEncalada et al. 2017). Changes in volume and timing of streamflow could have substantial implications for human and environmental water needs. These changes will create additional challenges and opportunities to coordinate releases with environmental flow needs.

\section{ENVIRONMENTAL FLOW STUDIES}

\section{The need for environmental flows}

Current patterns of water use (e.g., river diversions and groundwater overdraft), together with infrastructure development (e.g., proliferation of water intakes, dams, and levees) and pollution, have greatly altered the natural water regime of the Rio Grande/Bravo and had adverse impacts on local riparian and aquatic ecosystems. Recognition of the mounting threats to riparian and aquatic species in the Rio Grande/Bravo basin has led to increased consideration of environmental flow needs within water resources management efforts. Instream flow requirements, which consider only ecological water needs, are key for determining environmental flows because they define a set of initial flow targets from which flow regimes that balance human and ecosystem water needs are derived. Fundamentally, determining instream flows requires selecting appropriate estimation methods based on spatial scale, temporal resolution, data availability, technical requirements, costs, and ecological management goals (Tharme 1996, Arthington and Zalucki 1998, Arthington 2012). More than 200 methodologies exist for estimating instream flows (Tharme 2003), most of which fall into three distinct categories: hydrologic (e.g., Tennant 1976, EscobarArias and Pasternack 2010, Richter et al. 2012, Yarnell et al. 2015, 2020), habitat simulation (e.g., Tharme 2003, Arthington 2012), and holistic (e.g., Poff et al. 2017).

\section{Instream and environmental flows for the Rio Grande/Bravo}

In the last 15 years, multiple studies have been conducted to estimate instream flows in different locations and sections of the Rio Grande/Bravo basin. Table 1 presents a brief overview of some of these studies, which use varying instream flow methods and from which ecosystem water needs have been recommended. In addition, several other studies, listed in Table 2, evaluate the ability to adjust existing Rio Grande/Bravo water management strategies to provide instream flows while meeting human water management objectives, including agriculture and urban water supply, flood control, treaty obligations, and recreational and economic benefits. Two key insights emerge from a review of these studies. First, instream flows from which environmental flows can be derived have already been estimated for several locations and reaches (Fig. 3). Second, and notably, past studies indicate that even though the Rio Grande/Bravo is a heavily managed and allocated basin, it is feasible to provide environmental flows to maintain or restore aquatic and riparian ecosystems while still supplying agricultural water needs (Sisto 2009, Sandoval-Solis and McKinney 2011) and meeting treaty obligations (Lane et al. 2015). Furthermore, these water management changes are hydrologically (Lane et al. 2015) and economically viable (Ward 
Fig. 3. Locations in the Rio Grande/Bravo basin where instream flows have been estimated. The locations are derived from Table 2, which is not an exhaustive list.

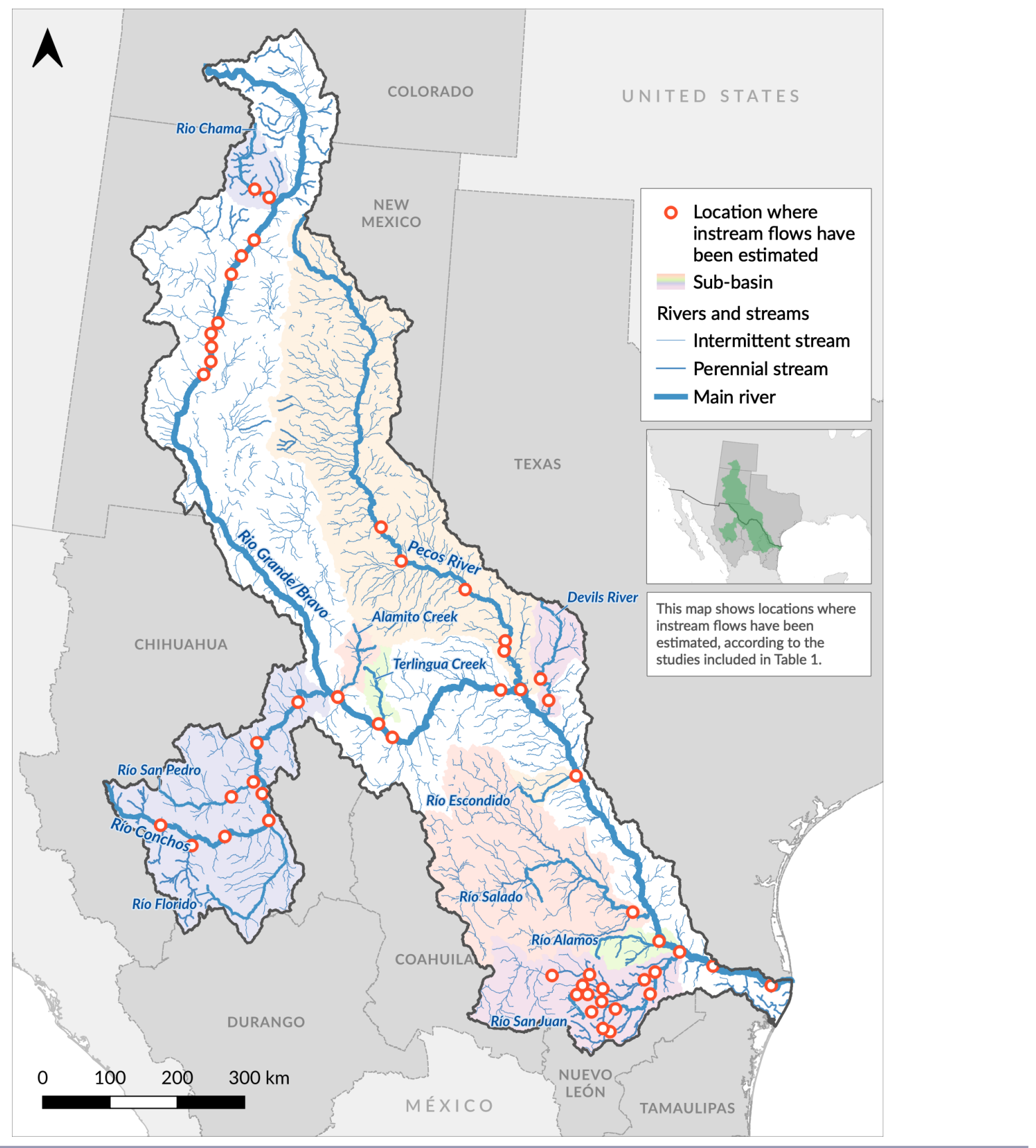

and Booker 2006, Ortiz-Partida et al. 2016). These findings indicate that the focus must turn to understanding the sociopolitical factors that influence whether and how environmental flows can be integrated into water policies and practices in the Rio Grande/Bravo.

\section{WATER GOVERNANCE AND ENVIRONMENTAL FLOWS}

Overview

In the water-scarce SES of the Rio Grande/Bravo, access to surface water is highly prized and contentious. Institutions and policies for water governance have developed incrementally over the last two centuries and represent the outcomes of changing and competing interests intersecting across local, regional, and national levels (Paulson et al. 2004), often at the expense of practices that offered alternative visions of integrating nature and society (Perramond 2016). The current formal water governance and policies of the Rio Grande/Bravo do not prioritize environmental flows. Yet the introduction of environmental flows as a public good implies explicit recognition and protection by the social institutions that mediate water access and management. 
Table 1. Examples of instream flow studies in the Rio Grande/Bravo.

\begin{tabular}{|c|c|c|c|c|}
\hline \multirow{2}{*}{$\begin{array}{l}\text { Location } \\
\text { Lower Rio Grande/Bravo } \\
\text { Matamoros and } \\
\text { Brownsville reach }\end{array}$} & \multicolumn{2}{|c|}{ Instream flow method } & \multirow{2}{*}{$\begin{array}{l}\text { Results } \\
\text { Estimations of a minimum seasonal environmental } \\
\text { flow for the lower Rio Grande/Bravo due to high } \\
\text { anthropogenic demand }\end{array}$} & \multirow{2}{*}{$\begin{array}{l}\text { Reference } \\
\text { de la Lanza Espino et } \\
\text { al. (2018) }\end{array}$} \\
\hline & Hydrological & $\begin{array}{l}\text { Percentage of average } \\
\text { annual runoff }\end{array}$ & & \\
\hline $\begin{array}{l}\text { Pilón River and San Juan } \\
\text { tributary to the lower Rio } \\
\text { Grande/Bravo }\end{array}$ & Hydrological & $\begin{array}{l}\text { Percentage of average } \\
\text { annual runoff and } \\
\text { modified Tennant } \\
\text { method }\end{array}$ & $\begin{array}{l}\text { Estimations of the minimum flow for the Pilon and } \\
\text { San Juan Rivers }\end{array}$ & $\begin{array}{l}\text { Zepeda-Martínez } \\
\text { 2012, Vidales- } \\
\text { Contreras et al. (2014) }\end{array}$ \\
\hline $\begin{array}{l}\text { Big Bend region and the } \\
\text { tributaries Rio Salado, Rio } \\
\text { Escondido, Rio Alamo, and }\end{array}$ & Hydrological & Percent flow & $\begin{array}{l}\text { Estimation of maintenance and dry season instream } \\
\text { flows }\end{array}$ & $\begin{array}{l}\text { Sandoval-Solis et al. } \\
\text { (2019) }\end{array}$ \\
\hline
\end{tabular}

Rio San Juan

Middle Rio Grande at San Hydrological Minimum flow

Acacia reach

Physical habitat simulation model

Independence Creek, Devils Habitat simulation River, and Pecos River
Middle Rio Grande Bernalillo, Central Ave, Bernardo, Bosque del Apache, San Marcial, and lower Rio Chama downstream from Abiquiu Reservoir Middle Rio Grande (Espanola, Pena Blanca, (Bernalillo and Escondida)

Habitat simulation 2-D hydrodynamic model

Habitat simulation Hydraulic criteria

Rio Chama tributary to the Habitat simulation upper Rio Grande

Rio Chama tributary to the Habitat simulation upper Rio Grande

Rio Grande basin upstream Holistic of Amistad Reservoir and below Presidio, including the Pecos and Devils river basins

Rio Conchos tributary to Holistic the Rio Grande
System dynamics modeling

1-D and 2-D hydrodynamic model

Physical and water quality habitat simulation model
A biological opinion issued that the minnow requires continuous minimum streamflow of at least 50 cubic feet per second over the San Acacia Diversion Dam A habitat-simulation model was built which considered a one-dimensional hydraulic model and habitat suitability criteria for certain species to estimate the weighted usable area for each species over a range of flows at all cross sections

A habitat-simulation model was built for several sites along the middle Rio Grande and lower Rio Chama to (2004), Stone (2008) support efforts to protect and enhance the Rio Grande. This model simulates flow, hydraulic variables, sediment transport, vegetation, water quality, and the ecology of the aquatic systems.

\section{USFWS (2001, 2003)}

Trungale Engineering \& Science (2012)

Mussetter et al.

Three habitat suitability curves were estimated using key variables (flow velocity, water depth, and substrate type) for mature and juvenile Rio Grande silvery minnow. Results showed the lack of adequate habitat for the Rio Grande silvery minnow within the main channel, and highlighted the importance of floodplain connection, where most of the appropriate mesohabitat resides.

A one-dimensional hydraulic model was developed using the recruitment box model (Mahoney and Rood (2015)

1998) to develop stage-discharge curves for cottonwood establishment and to determine the discharge at which overbank flooding occurs.

1-D and 2-D hydrodynamic modeling was used within Gregory et al. (2018) a collaborative process with the aim to improve spawning habitat for brown trout by flushing fine sediments from gravel features.

This study emphasized the relationship of high-flow pulses to sediment transport and channel geomorphology. It also evaluated water quality and biological overlay consisting of flow-instream habitat modeling for 10 focal fish species based on base flows and subsistence flow.

Horner (2016)

\author{
Morrison and Stone
(2015)
Gregory et al. (2018)
}

Rio Grande, Rio Grande Estuary, and lower Laguna Madre Basin and Bay Expert Science Team for the lower Rio Grande basin (2012) WWF (2006)

Estimation of instream flows, considering invertebrates) to determine the maintenance and drought flows necessary to sustain the river ecosystems for seven sites in the Conchos River

In this section, we review key formal water governance institutions and policies in the Rio Grande/Bravo, and ask in what ways do they appear to support or hinder the establishment of environmental flows. In a later section, other socio-political characteristics outside of formal governance institutions are considered.

\section{Polycentric and fragmented water governance}

The process of incorporating environmental flow recommendations into water management regulations and policies is a complex undertaking. Water governance in the Rio Grande/Bravo is characterized by a mosaic of institutions and regulations for water and land management that have either a direct or indirect impact on the establishment of environmental flows (Groenfeldt and Schmidt 2013, Poff and Matthews 2013, Nava and Sandoval-Solis 
Table 2. Examples of studies that have proposed environmental flows in the Rio Grande/Bravo.

\begin{tabular}{|c|c|c|c|c|}
\hline Location & $\begin{array}{l}\text { Reference for } \\
\text { instream flow study } \\
\text { (s) }\end{array}$ & $\begin{array}{l}\text { Water management } \\
\text { strategy }\end{array}$ & Results & Reference \\
\hline $\begin{array}{l}\text { Rio Conchos in Chihuahua } \\
\text { and the Rio Grande/Bravo } \\
\text { downstream of Fort } \\
\text { Quitman }\end{array}$ & WWF (2006) & Reservoir re-operation & $\begin{array}{l}\text { This study provides environmental flows in the Rio } \\
\text { Conchos basin while meeting treaty obligations and } \\
\text { water supply for users located in the lower Rio } \\
\text { Grande/Bravo basin, such as irrigation district } 025 \\
\text { Bajo Rio Bravo but affecting upstream irrigation } \\
\text { district } 005 \text { Delicias in Chihuahua. }\end{array}$ & $\begin{array}{l}\text { Sandoval-Solis and } \\
\text { McKinney (2009) }\end{array}$ \\
\hline $\begin{array}{l}\text { Rio Grande/Bravo in the } \\
\text { Big Bend Region }\end{array}$ & $\begin{array}{l}\text { WWF (2006) and } \\
\text { Upper Rio Grande } \\
\text { Basin and Bay } \\
\text { Expert Science } \\
\text { Team (2012) }\end{array}$ & Reservoir re-operation & $\begin{array}{l}\text { An alternative reservoir operation policy maximized } \\
\text { environmental flows to sustain key ecological and } \\
\text { geomorphic functions in Big Bend without } \\
\text { significantly impacting current water management } \\
\text { objectives. The proposed policy also improved water } \\
\text { supply provisions, reduced the average annual flood } \\
\text { risk, and maintained historical treaty provisions. }\end{array}$ & $\begin{array}{l}\text { Sandoval-Solis and } \\
\text { McKinney (2014), } \\
\text { Porse et al. (2015), } \\
\text { Lane et al. (2015), } \\
\text { Ortiz-Partida et al. } \\
\text { (2016) }\end{array}$ \\
\hline $\begin{array}{l}\text { Rio Conchos tributary to } \\
\text { the Rio Grande }\end{array}$ & WWF (2006) & Agro-economic model & $\begin{array}{l}\text { This study provides a proposal to restore and maintain } \\
\text { ecosystems on a stretch of the Rio Conchos in } \\
\text { northern Mexico, downstream of a large irrigation } \\
\text { district that consumes nearly all local flows. The study } \\
\text { provides estimates of environmental flow requirements } \\
\text { for these ecosystems and computes compensation } \\
\text { figures for irrigators. }\end{array}$ & Sisto (2009) \\
\hline $\begin{array}{l}\text { Rio Chama tributary to the } \\
\text { Upper Rio Grande }\end{array}$ & $\begin{array}{l}\text { Morrison and } \\
\text { Stone (2014) }\end{array}$ & $\begin{array}{l}\text { System dynamics } \\
\text { modeling }\end{array}$ & $\begin{array}{l}\text { This study examined the influence of flow regimes on } \\
\text { cottonwood recruitment and reservoir storage, and } \\
\text { investigated the impact of three alternatives on } \\
\text { cottonwood recruitment within the project reach. The } \\
\text { model attributed seedling survival to floodplain } \\
\text { elevation, annual timing of peak flows, and river stage } \\
\text { declines that match seedling root growth. }\end{array}$ & $\begin{array}{l}\text { Morrison and Stone } \\
(2015)\end{array}$ \\
\hline $\begin{array}{l}\text { Upper Rio Grande/Bravo } \\
\text { at San Acacia Reach }\end{array}$ & $\begin{array}{l}\text { U.S. Department of } \\
\text { Interior }(2001)\end{array}$ & $\begin{array}{l}\text { Integrated simulation } \\
\text { model }\end{array}$ & $\begin{array}{l}\text { This study estimated economic impacts associated } \\
\text { with one strategy for increasing instream flows to } \\
\text { protect critical habitat requirements of the endangered } \\
\text { Rio Grande silvery minnow. Using an integrated } \\
\text { hydrologic, economics, and allocation model of the } \\
\text { Rio Grande basin, a 44-year simulation of future } \\
\text { inflows to the basin was conducted to estimate } \\
\text { economic impacts of providing minimum acceptable } \\
\text { flows for the minnow. }\end{array}$ & Ward et al. (2006) \\
\hline
\end{tabular}

2014). Governance of the basin, riparian ecosystems, and associated lands is also divided according to the different functions, services, or utilities its human inhabitants have defined for them. The following are key characteristics of formal water governance that affect the establishment of environmental flows: (a) authority over water is distributed and nested across multiple political jurisdictions and spatial scales, with the qualification that in the United States it is more decentralized, and in Mexico it is more centralized; (b) authority over different aspects of environmental flows (e.g., water quantity, water quality) that sustain river ecosystems are divided across different agencies and institutions; (c) agricultural use is prioritized within the governance structures of both countries; (d) interstate and intercountry treaties and compacts for basin water sharing have been developed around existing patterns of water use, without significant provisions for environmental flows; and (e) groundwater and surface water have been effectively governed as separate bodies of water, even when hydrologically connected.

\section{Distributed and divided governance}

Water governance in the United States related to water rights, domestic and agricultural water supply, water quality, water flow, surface water, and groundwater is typically distributed across different institutions and/or different sets of regulations and policies. By contrast, in Mexico, most of these water governance functions come under the jurisdiction of the Mexican National Water Commission (Comisión Nacional del Agua [CONAGUA]). However, in both countries, there is a prevalent division between domestic and agricultural water supply governance, and between surface water and groundwater governance. In Mexico, only recently has CONAGUA begun efforts to regulate and manage surface water and groundwater use conjunctively to mitigate impacts on both surface flows and aquifers. In the U.S. portion of the Rio Grande/Bravo, efforts at conjunctive management of groundwater and surface water are localized, geographically dispersed, and relatively recent. Furthermore, policies that shape land, water, and species governance are similarly divided across institutions in both countries. For instance, forests, rangelands, protected areas and parks, agricultural lands, water supply, biodiversity, hunting and fishing are each governed by institutions with different if sometimes related, conflicting, or overlapping mandates. Natural resources include forests, rangelands, protected areas and parks, agricultural lands, water supply, biodiversity, hunting, and fishing. Thus, the establishment of 
environmental flows can be difficult due to competing governance policies, mandates, and interests, even within the same political jurisdiction. In the United States, the Endangered Species Act is a federal law that can override other governance objectives to mandate the restoration of ecological conditions, including environmental flows, but only when a species meets specific criteria of risk. In Mexico, in July 2000, the Wildlife Act (Ley General de la Vida Silvestre) was established; it is similar to the Endangered Species Act in that it also protects endangered species and habitats.

In both countries, there is also a variety of forms of land ownership, each with its own implications for land and water management objectives, policies, and regulations. In the United States, in addition to private landholdings, a substantial amount of land is owned and managed by federal and state agencies and by Native American tribal governments. In Mexico, in addition to private landholdings, there are two distinctive categories of land ownership that combine elements of both common property and private property: ejidos, areas of communally managed land where ejidatarios (members of the ejido) have a property deed for their parcels but share the responsibility of maintaining and protecting the land's resources as a group (Schumacher et al. 2019); and comunidades agrarias, similar to ejidos except that comuneros (members of the comunidades) cannot have a property deed for their parcels, and thus, cannot sell the land (Schumacher et al. 2019). Ejidatarios and comuneros (1) manage their own home lots and agricultural lands, and (2) manage collectively common use areas and resources, which can include forests, grazing lands, town facilities, and surface water for agricultural irrigation (Morett-Sánchez and Cosío-Ruiz 2017). There are some differences between them, including that comunidades are specifically intended for Indigenous communities (comunidades indigenas).

\section{Dominance of agricultural water rights}

An estimated $83 \%$ of the surface water in the Rio Grande/Bravo basin is allocated to agricultural use (Sandoval-Solis and McKinney 2011). Complicating this, surface water rights in both countries are over-appropriated: there are more rights to water than is normally available. Surface water rights in both countries are thus precious commodities, in high demand, increasingly sought by nonagricultural interests, and only reluctantly relinquished by farmers and landowners. Yet surface watersharing agreements among U.S. states and between the two countries are formulated primarily on the basis of water that has been allocated to agricultural use rights (although urban centers, especially in southern Texas below the Conchos, have increasingly acquired surface water rights). For instance, the water stored in Elephant Butte Reservoir is distributed according to the set of rules established for the Rio Grande Project and the Convention of 1906 to the irrigation districts of Elephant Butte Irrigation District, El Paso County Water Improvement District \#1, and Irrigation District 009 Valle de Juárez, and is almost exclusively destined for agricultural rights holders (Fig. 4). Thus, the introduction of environmental flows is challenged by the dominance of agricultural use rights and the water-sharing agreements based on them, and can be seen by farmers as competing with their own water needs.
Interstate compacts and international treaties

The Rio Grande/Bravo water-sharing legal framework is based on two binational agreements between the United States and Mexico (the 1906 Convention and the 1944 Water Treaty), and two compacts among the U.S. states (the Rio Grande Compact and the Pecos River Compact) (Nava and Sandoval-Solis 2014, Nava et al. 2016, Nava 2020). The 1906 Convention is a binational instrument that defines the amount of water to be delivered by the United States to Mexico for the primary purpose of irrigation; it establishes the distribution of surface waters of the Rio Grande/ Bravo at the international border between El Paso and Ciudad Juarez. The 1944 Water Treaty sought satisfactory utilization of shared surface waters based on equitable distribution between the two countries; it established water allocations and rules for the United States and Mexico, and the creation of the International Boundary and Water Commission (IBWC). The Treaty recommended three reservoirs for water storage along the mainstem of the Rio Grande/Bravo, two of which were constructed: Amistad and Falcon. The Treaty allocates one-third of the water reaching the Rio Grande/Bravo mainstem from six tributaries originating in Mexico to the United States and twothirds to Mexico. The U.S. third shall not be less than 432 million $\mathrm{m}^{3} /$ year (350,000 acre-feet/year), calculated as an average over a treaty cycle of five consecutive years.

Among U.S. states, the Rio Grande Compact, signed in 1929 and revised in 1939, provides for the allocation of the Rio Grande/ Bravo waters between the states of Colorado, New Mexico, and Texas at a level intended to protect water use as it existed from 1928 to 1937. The water of the Pecos River, the largest U.S. tributary of the Rio Grande/Bravo, is allocated between New Mexico and Texas through the Pecos River Compact, signed in 1948. Its purpose is to promote interstate collaboration and remove the causes of current and future water resources controversies. Droughts have triggered a change in regulations for water allocation, whether in international agreements (Convention of 1906 after the drought of 1892-1904, the binational water crisis of 2001 during the 1992-2007 drought) or in state water allocation systems (Texas Administrative Code 303 after the drought of 1942-1956). Historically, periods of drought have also resulted in more engineering of the river system; e.g., construction of reservoirs for water storage or increased groundwater use for agriculture. These intercountry and interstate agreements represent the few formal mechanisms that help knit together water governance perspectives across the basin as a whole, an important basis for establishing environmental flows. At the same time, they are the result of slow and politically sensitive negotiations, which are difficult to change, and can reinforce the prioritization of sub-basin interests. They were crafted during periods when stream flows were different from both current and projected conditions, and were built primarily around preserving agricultural water use.

\section{Water governance and environmental flows in the United States}

Water rights

In the United States, water rights are established at the state level of government. Surface water rights can be transferred among individuals, and under certain conditions can be separated from the land they are originally attached to. Changes in the uses of 
Fig. 4. Location of major irrigation districts, national and state parks, natural protected areas, and locations of interest. This is not an exhaustive list.

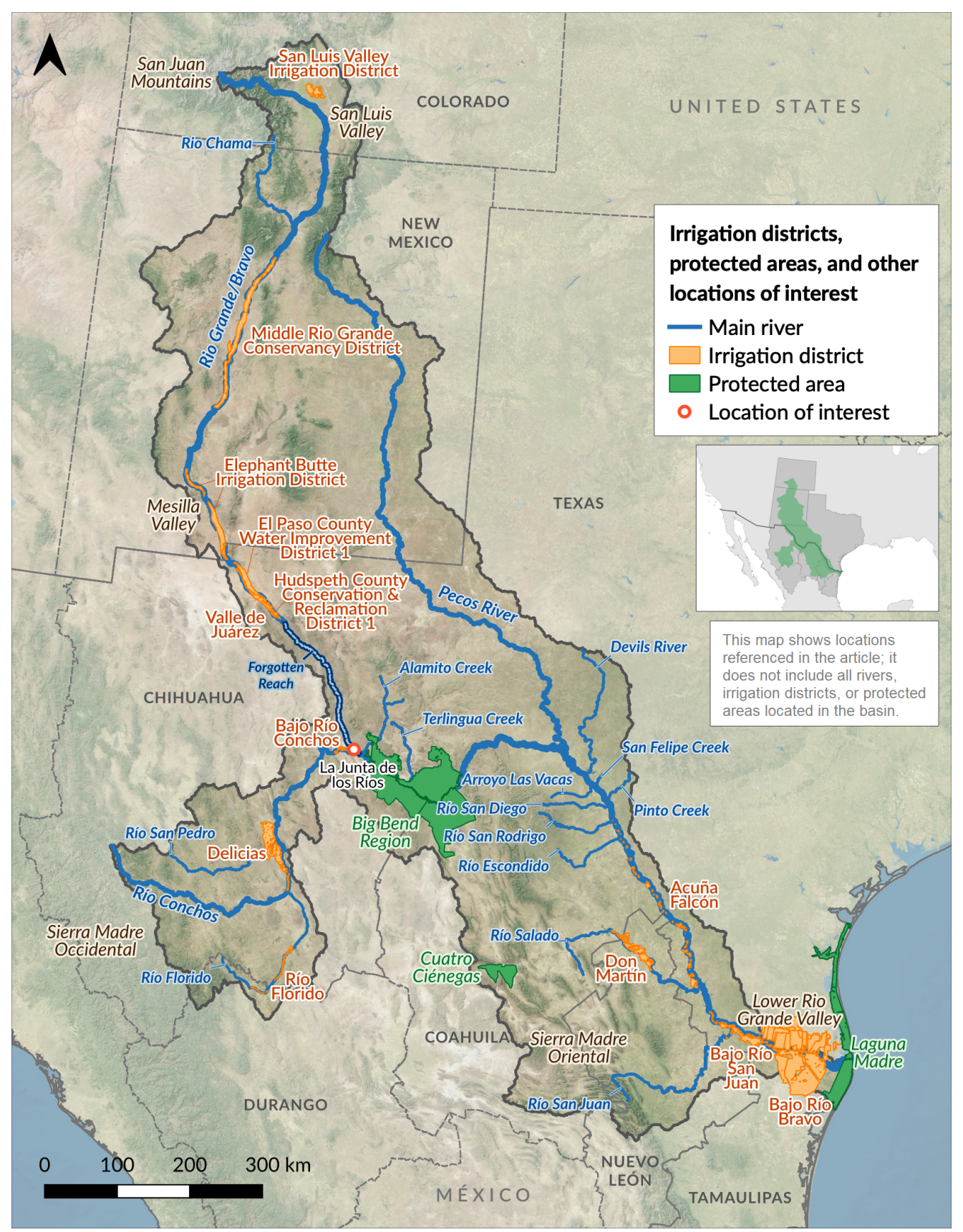

water rights (e.g., from agriculture to urban) must be petitioned for and adjudicated at the state level; this judicial process offers one challenge to the establishment of environmental flows. All three Rio Grande/Bravo states follow a "first in time, first in right" principle of surface water rights, where the earliest users of water have priority rights to water flow over those with later claims. The exception to this rule is the water allocation system below Amistad Dam to the Gulf of Mexico, where domestic, municipal, and industrial water right holders have priority rights from the water stored in Amistad and Falcon reservoirs over agriculture water right holders according to rules established for each water user type (Texas Administrative Code 303). Most surface water rights in New Mexico have never been fully adjudicated, which makes precise calculation and enforcement of surface water volume usage challenging. There are areas in Texas and New Mexico where often lengthy processes of water rights adjudication have been undertaken (Texas Administrative Code 303, Perramond 2018), which has posed additional challenges to water accounting for environmental flow purposes. 
Western U.S. water governance

In regard to water rights, the federal government's role is limited. In 1935, the court confirmed that the Desert Land Act of 1877 conveyed the land but gave "no common law right to the water flowing through or bordering upon the lands conveyed" (California Oregon Power Co. v. Beaver Portland Cement Co. et al. 1935). The court went on to hold that after the 1877 Act, "all non-navigable waters that are part of the public domain became publici juris, subject to the plenary control of the designated states"; thus, each state had the power to enact the type of water law it deemed appropriate. However, the court later recognized two limitations on state power (United States v. Rio Grande Dam \& Irrigation Co., 174 U.S. 690 1899): (a) a state cannot destroy the United States' right to the continued flow of a stream bordering government property if it is needed for a beneficial use on the property, and (b) it ensured "the uninterrupted navigability of all the navigable streams within the limits of the U.S." (Tarlock et al. 2002). Additionally, the federal government has the responsibility for location, construction, and management of federally funded reservoirs.

In the Rio Grande/Bravo basin, each state makes its own water laws and policy, and has specific state institutions that register, monitor, and enforce water rights and withdrawals, maintain water flow and use databases, initiate planning and projections for future water supply/demand, and represent the states in interstate compacts and agreements. Within the states, there is also a considerable amount of water governance and management authority distributed among a multitude of nested, and sometimes spatially overlapping, subregional and local institutions with different purposes, including various kinds of water management and conservancy districts, sub-basin councils, planning districts, irrigation districts, irrigation companies, acequias (community irrigation systems in New Mexico and southern Colorado) and other local ditch organizations, well-user groups, groundwater management districts, counties, and incorporated towns and cities. These institutions operate within the framework of state-established water use rights and regulations. They have considerable autonomy and authority in establishing and enforcing local regulations; researching, monitoring, and planning for local/subregional water conditions; shaping local/subregional water practices; and entering into collaborations and agreements with other institutions.

\section{Environmental flows}

Colorado

In 1973, Colorado enacted the Instream Flow Act to preserve water in natural streams and lakes to help preserve freshwater environments in the face of many competing demands. It allows the Colorado Water Conservation Board to appropriate new water rights and acquire existing water rights on a temporary (such as leasing) to permanent basis through "(1) new appropriations requiring detailed analyses of recommendations, processing, and adjudications of new instream flows; (2) acquisitions by analyzing, processing, and approvals of shortterm, long-term, and permanent acquisitions of water rights and interests in water; (3) physical protection, such as stream gaging and requesting administration; and (4) legal protection, such as water review, opposition, negotiation of decree terms, and litigation when needed" (Bassi et al. 2018). The rights are administered within the state's water right priority system.

\section{New Mexico}

Prior to 1998, New Mexico had no mechanism to implement environmental flows. Like other Rio Grande/Bravo states, the law required that water be diverted from the stream in order to constitute the basis of a water rights claim. Previous attempts to implement environmental flows through legislation had failed, but in 1984, an informal letter from the Attorney General's office suggested that under state law, instream flows were a beneficial use and a diversion was likely not required for instream flows (Fort 2000). However, in 1998, then Attorney General Tom Udall issued Opinion 98-01, addressing the question of whether the New Mexico state engineer had the authority to "afford legal protection to instream flows for recreational, fish or wildlife, or ecological purposes" (Udall 1998). The opinion stated that the state engineer had the authority to grant a change in use to an instream flow use and approve installation of gauges "to measure the instream flow beneficially used" (Udall 1998). The opinion did not address the question of new diversions because New Mexico's rivers are fully appropriated. The reality of implementing an environmental flow program is still a challenge, but through agreements and federal reserved rights for endangered species, and as a result of compact requirements, New Mexico is making strides in implementing environmental flows. In 2005, the New Mexico legislature enacted the Strategic Water Reserve, which "allows water or water rights to be designated for public purposes". The Reserve has two purposes: "to comply with interstate river compacts; and to assist the state and water users in efforts to benefit threatened and endangered species" (State of New Mexico Office of the State Engineer). New Mexico also established the River Stewardship Program, which grants funds to river restoration projects that enhance water quality and stream habitat and are implemented by Irrigation Districts, Soil and Water Conservation Districts, municipalities, Pueblos (Native American communities), nongovernmental organizations (NGOs), and others (Szeptycki et al. 2015).

\section{Texas}

In Texas, Senate Bill 2 (2001) required the implementation of an instream flow program, which is carried out by the Texas Water Development Board, the Texas Parks and Wildlife Board, and the Texas Commission on Environmental Quality. The agencies developed a Programmatic Work Plan and Technical Overview Document. The instream flow study goals identified in the Programmatic Work Plan are to "determine an appropriate flow regime (quantity and timing of water in a stream or river) that conserves fish and wildlife resources while providing sustained benefits for other human uses of water resources" (National Research Council 2005, TCEQ 2008). In addition to the development of an instream flow program, Chapter 15 Section 7031 established the Texas Water Trust under the Texas Water Bank to "hold water rights dedicated to environmental needs, including instream flows, water quality, fish and wildlife habitat, or bay and estuary inflows" (Texas Water Code, Title 2.C 1999).

\section{Water governance and environmental flows in Mexico}

\section{Water rights}

In Mexico, water is held in trust for the public good by the nation and is managed by the federal government by a single, centralized national institution, CONAGUA, which then offers concessions to individuals or entities for its use. Water policy in Mexico is 
based on a single legal instrument, the National Waters Law (Ley de Aguas Nacionales [CONAGUA 2004]), which applies to the entire country and has three main purposes: (a) specifies the federal ownership of all national waters (based on article 27 of Mexico's Constitution), (b) defines 13 basins as the spatial jurisdiction for water management and establishes water administration through basin councils, and (c) sets the rules for obtaining a water concession and defines the responsibilities, rights, and penalties of a water concession holder. The priority of water use specified in the Ley de Aguas Nacionales is assigned according to the type of use. Of the 11 water use types, the top five priorities are domestic, urban, livestock, agriculture, and wildlife conservation and environmental use. CONAGUA is in charge of monitoring, enforcement, planning, and policy, and granting water rights as concessions to individuals or entities. By means of the National Registry of Water Rights (Registro Público de Derechos de Agua), CONAGUA authorizes and keeps a record of water allocations for agricultural water use from surface water and groundwater sources and among a diversity of users.

\section{Water governance}

CONAGUA manages national waters by means of river basin councils. The Consejo de Cuenca del Río Bravo (Río Bravo Basin Council) acts as a multistakeholder consultative and planning body across the five Mexican states in the Rio Grande/Bravo basin. CONAGUA maintains its directive role through a network of state and municipal offices; personnel from these offices engage in water planning, infrastructure operation, and maintenance since they have the constitutional responsibility to ensure domestic water supply and water quality. Since the 1990s, increasing responsibilities for the internal operation and management of Distritos de Riego (federally established Irrigation Districts) have been transferred from CONAGUA to Distritos de Riegos. However, CONAGUA retains the authority for operation and management of reservoirs, dams, and water releases, and water allocations for agricultural use. The Ley de Aguas Nacionales describes the legal mechanisms for transfers of water concessions among irrigators within Distritos de Riegos, and for water concessions to be bought back from irrigators by the government and retired from use.

\section{Environmental flows}

In 2012, the federal government published the guidelines for estimating environmental flows at the national level. The Mexican Environmental Flows Norm (NMX-AA-159-SCFI-2012 [Secretaría de Economía 2012]) establishes the procedure and technical standards for determining the instream flow required for sustaining river ecosystems. The Norm aims to find a balance between human water use and water conservation for the environment; it provides a standardized approach for conducting environmental flow assessments, which consists of (a) providing guidelines for determining the current condition and degree of alteration of a given basin, (b) setting water conservation objectives for the environment in light of current and future human water demands, (c) assessing environmental flows requirements based on the analysis of the intra-annual and interannual variability of the natural and current flow regime, and (d) recommending methods for delivering science-based outcomes to decision-makers to determine the amount of water to be allocated as an environmental reserve volume, which should be linked back to the water conservation objectives to maintain or improve the current environmental condition of the basin. These guidelines specify that any instream flow methodology is acceptable as long as it considers the natural flow regime and seeks to restore (partially or fully) components of the natural flow regime to provide instream flows that directly benefit river and estuary ecosystems. The guidelines outline a method for determining the degree of alteration, and recommend four methods for developing instream flow requirements: two hydrologic methods based on unimpaired hydrology (Tennant and Modified Percent of Flow), one habitat simulation method based on hydraulic habitat (Instream Flow Incremental Methodology), and one holistic method based on expert understanding and available literature (Building Blocks Method). In 2015, the federal government established the Water Reserve Zones Program (CONAGUA 2011), which is a legal instrument (federal decree [SEMARNAT 2014, 2016]) to secure a volume of water for drinking water consumption and wildlife protection above any other water use. In 2018, 10 water reserves were established in Mexico, none of them in the Rio Grande/Bravo. In 2019, the World Wildlife Fund (2019) identified 189 additional zones to be added to this program; however, the zones have not yet been approved.

\section{CHALLENGES AND OPPORTUNITIES: A COMPLEX LANDSCAPE}

The water governance section shows that legal spaces for implementing environmental flows have opened in recent years, but the overall focus of water governance is still largely on other objectives. However, there is opportunity for change. Political institutions and policies are shaped by people and their interests, and in turn, these institutions and policies help shape peoples' environmental objectives and practices. In this section, we consider three factors across the Rio Grande/Bravo basin that affect the prospects for environmental flows. First, we consider tensions between the recognition that the Rio Grande/Bravo constitutes a water commons, and individuals' and institutions' ability to interact with it as such. Second, we consider implications of the prominent role of agriculture in both surface water rights and social identity and organization in the basin. Third, we consider the special nature of the Rio Grande/Bravo as the basis of a distinct region that happens to lie between two countries, which in turn causes it to become the site of competing national and regional interests that have little to do with the river.

\section{Paradoxes in the social perceptions and practices associated with the Rio Grande/Bravo: the challenge of managing for the commons}

Due to the interdependence of society and river ecosystems across the whole Rio Grande/Bravo basin on scarce water resources, plus the large-scale challenges posed by climate change, whole-basin perspectives and planning are critical to sustaining humannatural systems going forward. Yet the abilities of the basin's residents to interact with the river on a whole-basin basis, to effectively plan for and manage it as a common pool resource, are hampered by several factors that contribute to the hydraulic and social fragmentation of the river system: (a) divided and distributed governance and legal frameworks; (b) re-engineering of the river course, damming, and extensive water extraction; (c) locally varying histories of water use, management, and competition for water resources among water users, sectors, and 
political jurisdictions; and (d) varying objectives and interests at national, binational, state, and local levels, including along the border between the United States and Mexico. These dynamics have shaped the social, cultural, political, legal, and economic interactions with the river, which has a primarily local or subbasin focus. This has led to planning and management strategies that focus on one portion of the river and neglect broader, sustainable, whole-basin thinking that could treat the Rio Grande/Bravo as a commons. Effectively and practically, the river system is perceived and interacted with as if fragmented into many rivers, rather than as one river, with some notable exceptions. The term "compact cognition" (Koch et al. 2019) highlights how the distributed, multilevel governance systems, as well as compacts and treaties defending different jurisdictions' water access across the basin not only contribute to, but also end up reinforcing the fragmented quality of the basin as immutable and normal. Ethnographic fieldwork across the basin shows how this normalization of fragmentation can become almost invisible to people who use, manage, or advocate for the river, and effectively acts as a form of customary law for managing the river (Tidwell et al. 2004, Nava and Sandoval-Solis 2014, Nava et al. 2016, Broadbent et al. 2017, Duran-Encalada et al. 2017).

Competition for limited water resources across the arid/semi-arid basin (Phillips et al. 2011) can reinforce both perceptions and practices that treat the river as fragmented. In many cases, "the river" becomes reduced to the water that can be drawn from it, while the river itself is perceived as a means of conveyance for transporting that "good" from upstream to the ultimate water rights holder. Disputes over how water is allocated among individuals, organizations, sectors, and political jurisdictions are constant, and at least in the United States, make litigation over water rights and allocations a permanent feature of the social and hydrological landscape. At the same time, the compacts and treaties governing binational and interstate water sharing are the few institutional and political mechanisms that exist for constituting the Rio Grande/Bravo basin as a functional commons across so many jurisdictions and such a large spatial scale. While these legal agreements defend the participating jurisdictions' water interests, they also force them to monitor, estimate, maintain records for, plan for, communicate about, and take action based on real-time hydrological and social conditions across the basin.

Similarly, there are conservation and sustainability narratives in the basin that build connections between different regions of the Rio Grande/Bravo, although their sometimes localized focus still has the potential to negatively affect both upstream and downstream conditions. The river is seen in many instances as a critical connection among communities, and this has led to efforts to find common ground in managing the river's resources. There are locally based efforts throughout the Rio Grande/Bravo basin that are committed to protecting the river or rewriting the extractive narrative of the river: NGO-farmer partnerships to restore the river in Colorado; joint efforts between federal, state, and NGO actors to protect habitat for wildlife in New Mexico; governmental and academic partnerships to rethink water sustainability in the El Paso/Cd. Juarez region (Hargrove et al. 2013); and transborder community efforts to monitor water quality and conduct citizen science around Laredo-Nuevo Laredo. However, each of these activities is, in general, an ad hoc effort implemented to combat the normalization of fragmentation; their ability to effect long-term change is unclear.

Individual and institutional actors recognize that their past, current, and future well-being is closely tied to the sustainable management of the Rio Grande/Bravo (including surface water, ground water, and land management decisions), both upstream and downstream of their immediate management and decisionmaking areas. This understanding reflects a sense of the river as a commons, as well as values that deeply entwine the health and function of natural systems with the continuing flourishing of people and their communities. Nevertheless, structural constraints, cognitive factors, and socioeconomic-cultural dynamics (e.g., market forces, "use-it-or-lose-it" laws, or value systems) create a confluence of factors that often cause actual river management and water practices to undermine the shared health of the Rio Grande/Bravo commons.

\section{The central place of agriculture}

Attempts to implement environmental flows must deal with the critical place of agriculture as (1) the predominant surface water use, (2) an important economic and livelihood activity that takes different forms and has different relationships to the river, and (3) an important part of the socio-natural organization and identities of the basin. Agriculture is responsible for $83 \%$ of surface water use; thus, dedicating water to environmental flows can be perceived as yet another competing use. For instance, in the Río Conchos basin, environmental flow proposals can be seen by irrigation district farmers as adding yet another competing water use to a context where their water access is already under pressure to meet the Treaty of 1944 obligations to deliver Conchos water to the United States. In recent years, irrigation district farmers have changed this perception, acknowledging that water has, is, and will be transferred from the Río Conchos to the Rio Grande/ Bravo mainstem, and that it can be transferred in an environmentally beneficial pattern. Agricultural water rights holders put high priority on the preservation of their water rights and on keeping them connected to the land. This is frequently true even when agriculture is no longer a primary or viable source of livelihood, especially among populations that have been dispossessed of land and other rights and resources in the past; e.g., Indigenous communities in both countries, and Hispanos in New Mexico and Colorado (Ebright 1997). In addition, due to surface water rights laws in the U.S. states, water rights holders feel strong pressures to exercise their water rights in order to preserve them (i.e., "use it or lose it"). Once lost or separated from agricultural land, water rights are difficult to replace, given the over-appropriated nature of the basin. As a result, it is common for irrigation organizations to have internal arrangements that allow some form of water banking, water sharing, or temporary/ permanent transfer of water among members in order to preserve overall water rights attached to members' lands. In response to this issue, various initiatives allow temporary agricultural water transfers that keep water rights attached to the land, while at the same time explicitly supporting environmental flows and ecological restoration. Furthermore, agriculture is differentiated across the basin, and the implementation of environmental flows may pose different kinds of challenges or opportunities for different forms. In both countries, farming systems range on a spectrum from smaller scale, river-fed, floodplain irrigation, with Native American and Spanish colonial-era origins, to larger scale 
farming operations that originated in the 20th century and cultivate substantially larger acreages and broader extensions of the river valleys, which is made possible only by water storage in large reservoir projects and extensive systems of canal infrastructure.

Where agriculture is or was directly river-fed, knowledge of and a self-expressed relationship to river ecosystems tends to be strongest. In many cases, there is multigenerational knowledge of environmental change in the river ecosystem, and a strong sense of place that includes the river, associated species, wetlands, terraces, and floodplains as part of the social-ecological and cultural landscape, which has generated local efforts to reinforce that landscape through river restoration. These farming systems were developed on the basis of natural river pulses and wet-dry cycles; their endurance is in part considered to be due to this climate variability adaptation (Fernald et al. 2015). Environmental flow implementation could find complementarities with farmers toward this end of the spectrum in the Rio Grande/ Bravo basin. On the other hand, these systems generally represent the irrigators in the basin with the least capital and capacity to make major shifts in farming systems. If environmental flow measures add additional risks to these systems, they are unlikely to gain wide acceptance; if they can help enhance and strengthen them, they could be synergistic.

Where agriculture is dependent on large-scale, 20th-century hydrological infrastructure, it tends to be organized into some form of irrigation district. Some districts incorporated earlier small-scale, river-fed irrigation operations and organizations, while adding new extensions of irrigable land. Large-scale farming operations are also often multigenerational (albeit within a much shorter time frame), with a strong attachment to place and identity. But farmers often have relatively less relationship to and long-term knowledge of the river as an ecosystem: their access to irrigation water has almost always been mediated by reservoirs and canals. They are deeply knowledgeable about their lands and are keen observers of weather patterns, snowpack and precipitation, vegetation, and soil characteristics. But this kind of farming has developed in greater independence from the river ecosystem, and the river ecosystem has been more transformed in order to serve it, which likely has caused more decoupling between the two. The farm operations represent more highly capitalized businesses, with greater potential to invest in technological or other shifts. At the same time, the degree of technological and financial investment in current farming systems, including long-horizon perennial crops, puts them at high economic risk from reduced water resources. In contrast with small-scale irrigators, their access to water is more highly mediated by agreements among multiple layers of agencies, bureaucracies, and water-sharing compacts and treaties, which also makes easy shifts in policy or practices more challenging.

\section{The river as shared waters and as political boundary}

Due to the binational sharing of waters and the critical function of the river as a political border, management of stream flow, the river channel, and the river ecosystem in the border region serves multiple objectives, many of which are disconnected from or are in conflict with the maintenance of river ecosystem function (or even agriculture and water supply), and serve wider political, economic, and other shifting agendas, such as border security and control.
The construction of fences and other barriers, increasingly builtup border crossings, and the management of river vegetation (using herbicides that are washed out into the river) with the aim of controlling the crossing of people and goods, both legal and illegal, are some important features of the politicization of the river. Political tensions, law enforcement activities, and chronic violence associated with immigration, drugs, and cartel activities have combined to transform some areas of the border section of the Rio Grande/Bravo into a kind of no-man's land (Massey 2016), described by Roland (2020) as "the most militarized peacetime border in the world," where increasing numbers of human lives are put at risk and the imposition of national-level and organized crime agendas disrupt centuries-long social, cultural, and economic relationships among communities on both sides of the border and their relationship with the river as a source of livelihood and well-being. These tensions at the border are nothing new; however, since 2001, border security has increasingly driven U.S. national policy and action at the border, which has resulted in increased barrier construction and mobilization of border patrol forces, and has further put at risk the environmental protection of riparian boundary areas.

At the same time, multiple initiatives in the border region are working to counter the alienation of border communities from each other and from the river system. For example, the maquiladora system along the Mexico-U.S. border has mobilized Mexicans living there to organize around environmental deterioration and social and economic problems in the region (Moure-Eraso et al. 1994, Earhart 2012). The increasing focus on landscapes and watersheds as the objects of conservation has resulted in multiple projects, many of them cross-border, that approach the region as more of an SES. For instance, there are active calls among ecosystem restoration and recreational water interests below la Junta de los Ríos, in both countries, to find ways for releases from Luis L. Leon reservoir in the Río Conchos to better serve environmental flow purposes (Bennett et al. 2008). There have been localized initiatives to build on long-standing socio-environmental traditions that include restoration or preservation of river-centered ecosystems. And, recent intensification of U.S. policies to expand border wall construction and increase militarization of the border has produced new socioenvironmental movements to protect the river and associated lands, together with long-standing socio-cultural relationships.

\section{MEETING ENVIRONMENTAL FLOW NEEDS: EXAMPLES OF INITIATIVES}

The previous sections described several challenges to establishing environmental flows in the Rio Grande/Bravo and discussed ways in which biophysical heterogeneity, data limitations, water governance structures, political interests, and historical, social, cognitive, and economic factors contribute to preventing wholebasin thinking needed to integrate environmental flows into existing water management policies and practices. Similarly, we have described technical, governance, and socio-political frameworks on which the integration of environmental flows could be built, considering existing and new legal spaces within and across political jurisdictions to support environmental flows and related river restoration actions, as well as long-standing and emergent social foundations for merging social and ecological objectives for the river. 
Fig. 5. Examples of environmental flows initiatives.

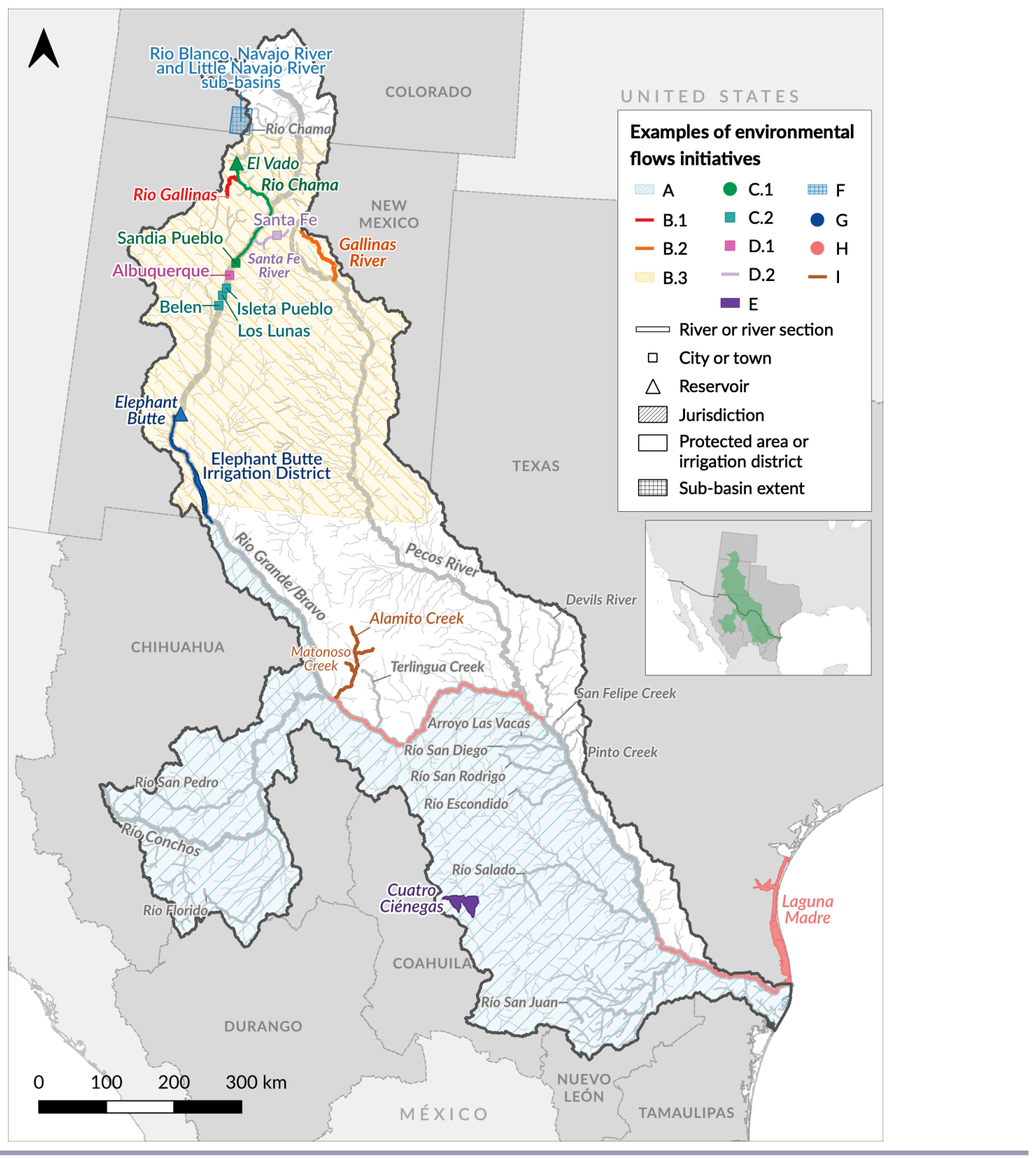

In this section, we highlight several examples (Fig. 5 and Appendix 1) in which environmental flows have begun to be implemented or supported in various locations throughout the Rio Grande/Bravo basin. Each example either takes a different approach and draws on some combination of existing forms of support for environmental flows or builds new ones. These examples operate at different spatial scales and timelines, involve different kinds of collaborations among institutions and sectors, look for ways to address multiple objectives among different parties, have a vision of water as a shared resource, and show potential paths toward the governance of a common-pool resource. These examples are not intended to be a comprehensive list; rather, they are potential models for integrating environmental flows in the Rio Grande/ Bravo, and by extension, in other arid zones of North America. They are meant to be followed, watched, analyzed, and learned from.

A. Inclusion of an environmental flows representative in a multistate, basin planning council: the Río Bravo Basin Council Consejo de Cuenca del Río Bravo, México

The Consejo de Cuenca del Río Bravo (CCRB) serves as a multistate venue for discussing challenges and reaching 
agreements related to water management in the Mexican portion of the Rio Grande/Bravo (Fig. 5: Example A). The CCRB stands out because of its trust, engagement, cooperation, and discussions among representatives of major stakeholder groups (e.g., water users, NGOs, and community organizations), water advisors (e. g., scientists and researchers), and technical advisory committees. Since its inception in 1999 , two technical advisory committees, the Specialized Modeling Group and the Legal Working Group, have met regularly to define water allocation rules using a humancentric vision of the basin. After the first water concession title was awarded for environmental flows (Fig. 5: Example E), a new, voting position was added to represent environmental water use, which was filled by the NGO Pronatura Noreste. The CCRB is the only river basin council in Mexico to include an environmental representative (Vocal Ambiental in Spanish) in its structure, and is known as the most specialized and proactive of the councils. Since the inclusion of the environmental representative in 2017 and the determination of environmental flow throughout the basin (Bennett et al. 2008, Sandoval-Solis et al. 2019), the CCRB is now considering environmental flows as an integral part of a new regulatory framework for allocating water to the Mexican water users of the Rio Grande/Bravo.

Including environmental flows as part of the proposed rules for water allocation and water transfers between reservoirs was not an easy task and required a change in the mindset of the council representatives. Currently, the top four water use priorities in the basin (domestic, urban, livestock, and agriculture) account for more than $95 \%$ of the consumptive water use in the Mexican portion of the Rio Grande/Bravo basin. A key argument was that environmental flows are not adding another consumptive use; they can be supplied by transferring water from upstream to downstream reservoirs in an instream flow pattern, which is similar to the arrangement used in Rio Chama with the Heron, El Vado, and Abiquiu reservoirs (Fig. 5: Examples C.1 and C.2). While the volume of water for environmental flows can be small compared to the natural flow regime, including environmental flow in the regulatory framework opens the door to managing water for environmental objectives. In the Specialized Modeling Group, environmental flows are now considered in the proposed water allocation rules of the Rio Grande/Bravo, shifting to a human-environmental perspective. In the last decade, the Council promoted the creation of Specialized Groups on Wetlands, Water Education and Culture, Payment for Environmental Services, Strategic Planning, and Treaty Deliveries (CCRB 2018). These efforts have the potential to positively influence water policy on the implementation of environmental flows and the establishment of priority wetlands along the basin.

\section{B. Leasing of agricultural water rights for environmental flows: New Mexico}

\section{Example B.1}

In November 2019, the New Mexico Office of the State Engineer issued the first state instream-flow water permit for a stretch of the Rio Gallinas (Fig. 5: Example B.1), just upstream of its confluence with the Rio Chama, a tributary of the Rio Grande/ Bravo. The New Mexico Office of the State Engineer granted the permit to the NGO Audubon. The permit allows the water right holder to leave water in the river rather than diverting it and thus avoid the risk of losing rights for lack of putting them to beneficial use. Audubon's permit allows for a 5-year lease of an agricultural water right for environmental flows. This approach provides an opportunity for farmers to derive some economic benefit during times when farming might not be cost-effective or they do not want to farm (Chamberlain 2019, Tashjian 2019).

Example B.2

Trout Unlimited, another NGO, secured the second New Mexico permit to lease agricultural water rights $\left(5\right.$ acre-feet $\left[6167 \mathrm{~m}^{3}\right]$ per year) for instream flow to preserve native cutthroat trout on Gallinas Creek in San Miguel County (Pecos River sub-basin) (Fig. 5: Example B.2). Accomplished in collaboration with a local landowning family, this kind of arrangement allows local landowners to preserve the active use of their water rights, keep them connected to family land, and at the same time, help preserve riparian ecosystems, thus meeting several environmental and social objectives at the same time (Peterson 2020). Very recently, The Nature Conservancy included the Pecos River in the list of advancing projects in its Sustainable Rivers Program (TNC 2020).

Example B.3

In 2005, the New Mexico legislature enacted the Strategic Water Reserve (OSE 2020), which "allows water or water rights to be designated for public purposes" (Fig. 5: Example B.3). It also provided funding to lease or purchase water rights. As of January 2018, three leases had been signed and four purchase agreements had been executed for a total of 1099 acre-feet $\left(1.356 \times 10^{6} \mathrm{~m}^{3}\right)$ of water for the Rio Grande/Bravo above Elephant Butte, and 1583 acre-feet $\left(1.953 \times 10^{6} \mathrm{~m}^{3}\right)$ for the Pecos River (OSE 2018). The purchases and leases were to protect endangered species and to meet Rio Grande and Pecos River Compact requirements. In March 2020, the New Mexico Legislature appropriated \$750,535 to the Strategic Water Reserve to purchase additional water rights (New Mexico Legislature 2020).

\section{Voluntary releases of unused water in reservoirs for environmental flows: New Mexico}

\section{Example C.1}

The New Mexico Audubon Society, working with the Pueblo of Sandia to restore flows in the Rio Grande, offered to buy water rights from the Pueblo, but instead, the Pueblo did a one-time donation of 101 acre-feet $\left(124,581 \mathrm{~m}^{3}\right)$ of water that was stored in the El Vado Reservoir, which was released in 2016 to help restore the river's ecosystem (Audubon 2015, Paskus 2015) (Fig. 5: Example C.1). This was the first but not last donation of its kind.

\section{Example C.2}

In July 2018, while the Rio Grande was experiencing severe dry conditions, the New Mexico Audubon Society formed a partnership with the Middle Rio Grande Conservancy District, the Bureau of Reclamation, the Pueblo of Isleta, and the Albuquerque Bernalillo County Water Utility Authority to release 994 acre-feet $\left(1.226 \times 10^{6} \mathrm{~m}^{3}\right)$ of water into a 34 -mile $(54.7$ $\mathrm{km}$ ) reach of the middle Rio Grande, downstream of the Isleta Diversion dam, to sustain wetlands, riparian habitats, birds, and wildlife in the areas of Isleta Pueblo and the towns of Los Lunas and Belen (Fig. 5: Example C.2) (Audubon 2018).

\section{Municipal ordinances to establish environmental flows: Santa Fe and Albuquerque, New Mexico}

\section{Example D.1}

In 2012, the city of Santa Fe passed a Living River ordinance that allows up to 1000 acre-feet $\left(1.233 \times 10^{6} \mathrm{~m}^{3}\right)$ of water per year to 
flow down the stream in normal and wet years, purely to maintain the river ecosystem (Fig. 5: Example D.1). The Santa Fe River target flows can be revised downward in drier years when the forecast for runoff from mountain snows is $75 \%$ or less of the 30 year annual average (City of Santa Fe 2013).

\section{Example D.2}

Similarly, the city of Albuquerque has restructured its water supply to ensure a minimum flow of $70 \mathrm{cfs}\left(1.98 \mathrm{~m}^{3} / \mathrm{s}\right)(50 \mathrm{cfs}[1.42$ $\left.\mathrm{m}^{3} / \mathrm{s}\right]$ for fishway bypass and $20 \mathrm{cfs}\left[0.57 \mathrm{~m}^{3} / \mathrm{s}\right]$ for sediment movement) below the city's central stream gauge, which contributes to the maintenance of downstream riparian and riverine habitats (Appendix 1 and Fig. 5: Example D.2) (Water Utility Authority 2016).

\section{E. First environmental water right: Cuatro Ciénegas, México}

In 2014, CONAGUA awarded, for the first time in Mexico, surface water concession title for environmental use to the NGO Pronatura Noreste, which it applied in Cuatro Ciénegas Valley, one of the most important wetlands in the Chihuahuan desert and the Rio Grande/Bravo (Fig. 5: Example E). Cuatro Ciénegas is a protected area recognized for its exceptional biodiversity, including the greatest number of endemic species of any place in North America (Stein et al. 2000), and has been affected greatly by the intensification of high-water-demand crops and water exports outside the basin. This historic environmental water concession sets several legal precedents for future water resources conservation in Mexico, including (1) the provision of environmental water use concessions, based on the human right to a healthy environment (CNDH 2014), (2) the legitimacy of an organization to stand for the environment against third parties and threats to the ecological balance of hydrological basins, and (3) the setting aside of water for the environment in overallocated watersheds through transfer of concessions, conversion from agricultural to environmental use, and water reserves for the environment (CONAGUA 2004).

Pronatura Noreste has been a key figure in introducing environmental water concessions into Mexican legislation and in representing the environment as a water user in the Rio Grande/ Bravo. However, the acquisition of ecological water concessions remains challenging because there is more water available on paper titles than actually exists in the basin. In addition, the transfer of water concessions poses additional layers of complexity to the acquisition of environmental water concessions. Nonetheless, this unprecedented event's success lies in recognizing the legitimacy of public environmental water concessions for environmental preservation as a beneficial use; it also helps create awareness of the urgency for allocating water to the environment and mobilizes stakeholders to discuss potential environmental flow policies.

\section{F. Cross-sectoral, cross-jurisdictional, and cross-boundary collaboration in forest management for water quality and flow: Colorado and New Mexico}

Some of the structural challenges that make it difficult to introduce successful, conservation-focused management in the Rio Grande/Bravo basin - especially challenges associated with fragmented water rights and basin-wide obligations to transfer water from one region to another-have also resulted in innovative and unexpected approaches to protecting the river. The Nature Conservancy in New Mexico saw the damage caused to water quality that resulted from a number of wildfires that occurred near riparian forest zones in southwest Colorado in 2011. Though these forests are in areas that are under the management of the U.S. Forest Service, there were few resources available to conduct the forest thinning that would be necessary to reduce the risk of wildfire impacts in runoff, such as ash, soil, and trees/debris that impacted the water quality of the Rio Chama, which feeds into the Rio Grande/Bravo, and clogged the river and impacted dam operations in New Mexico. The Nature Conservancy worked with state agencies, local municipalities, and community-level donors across New Mexico to create the Rio Grande Water Fund and help finance thinning and better management of forests in southwest Colorado, despite the fact that those forests are outside the Rio Grande basin (they are located in the Rio Blanco and Navajo River basins, which export their waters to the Rio Grande/Bravo) and in the state of Colorado (Hartwell et al. 2016). In other words, The Nature Conservancy demonstrated the kind of whole-basin thinking (as opposed to compact cognition) that is both rare and required to improve the sustainability of the Rio Grande/Bravo as a whole (Fig. 5: Example F).

\section{G. Adapting irrigation district policy to accommodate river restoration and agricultural water rights below Elephant Butte: New Mexico}

The section of the Rio Grande/Bravo from Elephant Butte Reservoir to El Paso, Texas was significantly channelized starting in the 20th century, which disrupted normal flows and meander patterns that supported local species and habitat. Yet this segment of the river includes areas that could be considered critical habitat under the Endangered Species Act for species such as the Southwestern Willow Flycatcher (Empidonax traillii extimus). In addition, the IBWC (U.S. Section) began efforts in 2009 to support habitat restoration at several sections of the river. However, all surface water available in this section of New Mexico is already designated for agricultural use within the Rio Grande Project. Changing water rights here from agricultural to other uses would require an extensive legal process. In 2013, Elephant Butte Irrigation District, which administers and distributes irrigation waters to southern New Mexico farmers, adapted its internal policy to make it possible for member irrigators to temporarily or permanently transfer some or all of their agricultural water rights to environmental use within Elephant Butte Irrigation District's area of operation (Fig. 5: Example G). Any such transfers are still subject to the same conditions as irrigation water: the amounts allocated per water right each year will be reduced or increased (within the maximum allowable) in the same proportions as for all agricultural water rights holders, based on conditions in Elephant Butte Reservoir, and they must be applied to lands within the Elephant Butte Irrigation District's area of jurisdiction. The Environmental Water Transaction Program was developed in conjunction with the IBWC (U.S. Section), which allowed the IBWC to lease, buy, or receive donations of agricultural water rights to apply to environmental flows for habitat restoration. By recognizing that watering native species is also a form of irrigation, Elephant Butte Irrigation District made it possible for water that was not needed by member farmers to be used toward environmental flows without having to legally change its beneficial use designation. 


\section{H. Environmental flows science advisory groups in Texas} In 2007, the Texas legislature passed the House and Senate Bill 3 Environmental Flow Program (TWDB 2020) to develop environmental flow recommendations based on the best available science and stakeholder involvement. The Bill established Environmental Flows Advisory Groups and Science Advisory Committees, which allowed diverse interest groups to discuss the costs and benefits incurred by environmental flows scenarios (Roach 2013). For the Rio Grande/Bravo, two expert teams - the Upper and Lower Rio Grande Basin and Bay Expert Science Teams - were formed to estimate instream flows in the Big Bend area (from Presidio to the Amistad Dam) and at the Rio Grande/ Bravo estuary (from Falcon Dam to the Gulf of Mexico) (Fig. 5: Examples H.1 and H.2) (TCEQ 2012). The teams produced key reports that determine instream flows along the border and in the estuary of the Rio Grande/Bravo (TCEQ 2012). The Big Bend is a region of the highest ecological interest, from the ecosystem services that it provides (domestic use, irrigation, recreation, tourism, and aquifer discharge into the mainstem) to the highquality habitat and refugia it provides to the Chihuahuan desert ecosystem.

In addition, the Texas Environmental Flows Science Advisory Committee and Basin and Bay Area Stakeholders Committee provide venues for public and state agency participation in recommending and implementing environmental flow measures (TCEQ 2020). This scheme was created by the 80th Texas Legislature to recognize the ecosystem services that riverine, bay, riparian, and estuarine ecosystems provide to social-ecological systems. Planning is based on local stakeholder and technical expert recommendations regarding environmental flow. The environmental flow process in Texas aims to apply the best available science and public input to water management policies that guide state agencies in managing and conserving human and environmental needs.

\section{Nongovernmental organizations promoting social-ecologically based land and water management for conservation: West Texas} In 2003, a rancher in Hudspeth County granted 1236 acre-feet $\left(1.5 .25 \times 10^{6} \mathrm{~m}^{3}\right)$ per year to provide water for fish and wildlife in the Rio Grande/Bravo; this is the first water rights donation in Texas to the Rio Grande/Bravo through the Texas Water Trust (TWDB 2006). This donation set a precedent for other Texas water users to follow. In addition to the state and regional water trust, the Trans-Pecos Water and Land Trust is the state's first private water trust. It has collaborated with the Dixon Water Foundation NGO to preserve almost 1400 acres (567 ha) of Alamito Creek watershed, designated as the Alamito Creek Preserve (Fig. 5: Example I). The area includes a 3.5-mile (5.6$\mathrm{km})$ riparian zone of Alamito Creek and a shorter segment of Matonoso Creek. The segment of Alamito Creek is recommended by the Far West Texas Regional Water Planning Group as an "Ecologically Unique River and Stream Segment" (TCEQ 2012). Building partnerships between private landowners and conservation organizations is critical in conserving riparian ecosystems, mainly because large portions of the land alongside tributaries such as Terlingua and Alamito Creeks are privately owned. Water rights donations and conservation projects aimed to improve instream flows and habitat, water quantity and quality, and removal of exotic species, which will contribute to native species' persistence and a healthy river (Desert Fish Habitat Partnership 2016).

\section{CONCLUSIONS}

\section{Initiatives discussion}

We examined the social and natural contexts for implementing environmental flows in the Rio Grande/Bravo basin, and stressed both the challenges and opportunities they present and the importance of treating the Rio Grande/Bravo as a continuous, dynamic, and complex SES. The environmental flows initiatives we have documented suggest that (a) it is possible to implement environmental flows despite the formidable physical, socioeconomic, cognitive, and institutional challenges facing the Rio Grande/Bravo, its large spatial scale, and its transboundary nature; (b) the actors involved worked from a concept of water as a shared resource, and found creative ways to approach the governance of a common-pool resource within existing legal frameworks; and (c) their implementation is dependent on regional context and collaborations, although lessons can be learned and transferred elsewhere. These initiatives have provided water allocations for environmental flows that were permanent (D1, D2, E, I) or were temporary, through leasing of agricultural water rights $(\mathrm{B} 1, \mathrm{~B} 2$, and $\mathrm{B} 3)$ or voluntary releases of water $(\mathrm{C} 1$, C2); created policy mechanisms for implementation (A, B3, G); provided spaces for environmental flow representation in decision-making bodies (A, H); and worked across political jurisdictions to support water flow and quality (F). These initiatives show some creative ways in which agricultural, municipal, and environmental flow needs have begun to be addressed conjunctively and how multiple actors have designed local or subregional approaches to providing environmental flows that do not require major structural changes. They highlight the importance of building partnerships; facilitating ways that address varying interests of multiple parties; identifying and addressing risks to water rights, livelihoods, and other objectives that environmental flows could present; and building empathy and respect among diverse groups.

Significantly, many of these initiatives address concerns about competition between agricultural and environmental water use. For instance, by developing options that allow temporary and conditional use of agricultural water rights for environmental purposes, they provide agricultural water rights holders the security to engage while still retaining their rights and options for future agricultural use. These examples show innovative navigations of difficult regulatory frameworks and socio-political challenges to support the implementation of environmental flows. They counteract the common belief in the arid west that water is only for fighting over with evidence that it is also for collaborating around (Fleck 2016). Nonetheless, current policies, regulations, and water governance frameworks are trapped in the inertia and legacy of the last two centuries and have not, in most cases, made the formal, long-term changes that would ensure environmental flows are maintained as an integral part of water resources management into the future. Recent efforts have suggested a number of viable and sustainable ways to integrate environmental flows into the future management and governance frameworks of the Rio Grande/Bravo. The years to come will reveal if there is enough political will and societal pressure to pass these regulations and change the ways we are managing water today. 


\section{Whole-basin thinking}

The dependence of the entire basin on a very few, remote sources of surface water requires whole-basin thinking and cooperation to meet human-environmental water needs, especially with the current effects of climate change. In the last few decades, there have been increasing efforts among scientists, water resource managers, citizens, and decision-makers to approach the Rio Grande/Bravo with a cross-boundary, whole-basin perspective. More actors are seeing challenges and solutions in the context of the Rio Grande/Bravo as a complex SES. These trends, we believe, are critical for finding common ground and designing solutions to ensure environmental flows across the Rio Grande/Bravo basin that supply water to all users - human and environmental.

\section{Including social, governance, and political aspects in environmental flow strategies}

A considerable number of studies have determined instream flows and proposed water management strategies for implementing environmental flows. They have advanced our understanding of the Rio Grande/Bravo. Instream flow studies can be used as a starting point for proposing ecosystem water needs, and to test innovative water management strategies to implement environmental flows. Technical solutions are important; however, any environmental flow studies must include social, water governance, and political aspects. As we have shown, it is not possible to decouple the social, political, economic, hydrological, and ecological aspects from each other; thus, environmental flow policies must consider the Rio Grande/Bravo as a complex, dynamic, and social-ecologically constituted system. Failing to do so will generate many fine technical studies, but they will likely remain infeasible or will not be implemented. Restoring the Rio Grande/Bravo flow regime to conditions that pre-date large-scale human settlement and 20th century farming is unrealistic, given the substantial engineering of the river, extensive biophysical changes, increasing anthropogenic water demands, and effects of climate change. However, we see many opportunities for strategies that can begin to re-establish and/or maintain environmental flows within the current social-ecological dynamics of the basin.

\section{Water management strategies into the future}

One win-win environmental flow strategy can be envisioned by rethinking surface water storage and reservoir operations. For instance, the current infrastructure of the Rio Grande/Bravo presents opportunities for updating reservoir operations to maximize beneficial use by providing environmental flows for river connectivity and maintaining native vegetation (Ahn et al. 2018, Fuchs et al. 2018) while reducing evaporative losses from reservoirs (Eichinger et al. 2003), especially during wet years. Water transfers among reservoirs are occurring with or without environmental flows policies; we are proposing to advocate for the exact same amount of water releases from reservoirs but in environmentally beneficial patterns. This approach can be augmented by riparian vegetation management to remove highwater-use species (e.g., saltcedar [Tamarix spp.]) to create a mosaic of riparian habitat that requires less water (Fullerton and Batts 2003). Furthermore, coupling these strategies with local restoration projects may create sequential pockets of native riparian habitat (i.e., "string of pearls" [Stanford and Ward 1993]) that will extend the effect of environmental flow strategies. There is a need for a system-wide information exchange and knowledge sharing about localized and regional restoration efforts and other innovative measures to support environmental flows (Fullerton and Batts 2003). Coordinated restoration efforts founded on strong understandings of different actors' water objectives and risks, along with public awareness campaigns can facilitate dissemination of knowledge, data, best practices, and environmental flow schemes that benefit different stakeholder groups along the river (e.g., instream and downstream uses).

Another technical option is to support the development of improved methods for reducing agricultural water use, with the ultimate goal of re-establishing a more natural flow hydrograph. In fact, adoption of many water-conserving technologies and practices is already underway in the basin, including increasing microbial activity, organic matter, and water retention in soils; increasing the precision and efficiency of irrigation equipment and practices; modifying cropping systems and crops grown; and increasing the efficiency of water distribution infrastructure. Yet the agricultural sector's water needs remain formidable and greatly limit the possibilities for securing sustainable environmental flows. We discuss future research topics related to agriculture and environmental flows in Appendix 2.

Responses to this article can be read online at: https://www.ecologyandsociety.org/issues/responses. php/12944

\section{Acknowledgments:}

Most of the authors of this paper were funded by the South Central Climate Adaptation Science Center of the United States Geological Survey, with project numbers G20AC00067, G15AP00132, G15AP00132, and G19AP00038. An author of this project, Dr. Luzma Nava, works for CONACYT, the Ministry of Science in Mexico.

\section{Data Availability:}

The data and files for the maps that support the findings of this study are available in HydroShare at: Sandoval-Solis, S., and B. A. Lane. 2021. Rio Grande - Río Bravo environmental flows database. Data and tools. https://doi.org/10.4211/hs.76bd2b2e36aa4f23920b20e5a5accb2a These data were derived from the following resources available in the public domain: https://www. sciencebase. gov/catalog/item/58e52181e4b09da679997bed

\section{LITERATURE CITED}

Ahn, S., S. Abudu, Z. Sheng, and A. Mirchi. 2018. Hydrologic impacts of drought-adaptive agricultural water management in a semi-arid river basin: case of Rincon Valley, New Mexico. Agricultural Water Management 209:206-218. https://doi. org/10.1016/j.agwat.2018.07.040

Arthington, A. H. 2012. Environmental flows: saving rivers in the third millennium. First edition. University of California Press, Berkeley, California, USA.

Arthington, A. H., A. Bhaduri, S. E. Bunn, S. E. Jackson, R. E. Tharme, D. Tickner, B. Young, M. Acreman, N. Baker, S. Capon, A. C. Horne, E. Kendy, M. E. McClain, N. L. Poff, B. D. Richter, 
and S. Ward. 2018. The Brisbane Declaration and Global Action Agenda on Environmental Flows 2018. Frontiers in Environmental Science 6:45. https://doi.org/10.3389/fenvs.2018.00045

Arthington, A. H., and J. M. Zalucki, editors. 1998. Comparative evaluation of environmental flow assessment techniques: review of methods. Land and Water Resources Research and Development Corporation, Canberra, Australia.

Audubon. 2015. In a groundbreaking move, Pueblo of Sandia donates water to birds and other wildlife. [online] URL: https:// www.audubon.org/news/in-groundbreaking-move-pueblo-sandiadonates-water-birds-and-other-wildlife

Audubon. 2018. Audubon joins New Mexico municipalities in water releases to recharge vital habitat along the Rio Grande. [online] URL: https://www.audubon.org/news/audubon-joinsnew-mexico-municipalities-water-releases-recharge-vital-habitat

Balvanera, P., A. B. Pfisterer, N. Buchmann, J.-S. He, T. Nakashizuka, D. Raffaelli, and B. Schmid. 2006. Quantifying the evidence for biodiversity effects on ecosystem functioning and services. Ecology Letters 9(10):1146-1156. https://doi.org/10.1111/ j.1461-0248.2006.00963.x

Bassi, L. J., S. J. Schneider, and K. M. White. 2018. ISF Lawstories about the origin and evolution of Colorado's Instream Flow Law in this prior appropriation state. University of Denver Water Law Review 22:389.

Bennett, J., A. Robertson, J. Hoth von der Meden, and J. Schmidt. 2008. A vision for the Big Bend Reach of the Rio Grande/Rio Bravo. Bi-National Workshop, Sul Ross State University, Alpine, Texas.

Bhattacharjee, J., J. P. Taylor, L. M. Smith, and D. A. Haukos. 2009. Seedling competition between native cottonwood and exotic saltcedar: implications for restoration. Biological Invasions 11(8):1777-1787. https://doi.org/10.1007/s10530-008-9357-4

Blythe, D. E. 2018. Assessing the ecological implications of the altered flow and sediment regimes of the Rio Grande along the West Texas-Mexico border. Dissertation, Utah State University, Logan, Utah, USA.

Blythe, T. L., and J. C. Schmidt. 2018. Estimating the natural flow regime of rivers with long-standing development: the northern branch of the Rio Grande. Water Resources Research 54 (2):1212-1236. https://doi.org/10.1002/2017WR021919

Broadbent, C. D., D. S. Brookshire, D. Coursey, and V. Tidwell. 2017. Futures contracts in water leasing: an experimental analysis using basin characteristics of the Rio Grande, NM. Environmental and Resource Economics 68(3):569-594. https:// doi.org/10.1007/s10640-016-0032-4

Cayan, D. R., T. Das, D. W. Pierce, T. P. Barnett, M. Tyree, and A. Gershunov. 2010. Future dryness in the southwest US and the hydrology of the early 21 st century drought. Proceedings of the National Academy of Sciences of the United States of America 107(50):21271-21276. https://doi.org/10.1073/pnas.0912391107

Chamberlain, K. 2019. New Mexico grants water rights to keep water in a river. [online] URL: https://nmpoliticalreport. com/2019/12/13/new-mexico-grants-water-rights-to-keep-water-ina-river/
City of Santa Fe. 2013. A river runs through it! [online] URL: https://www.santafenm.gov/news/detail/a_river_runs_through_it

Comisión Nacional de los Derechos Humanos (CNDH). 2014. El derecho humano al medio ambiente sano pare el desarrollo y bienestar. Comisión Nacional de los Derechos Humanos, Mexico.

Comisión Nacional del Agua (CONAGUA). 2004. Ley de aguas nacionales y su reglamento. Secretaría del Medio Ambiente y Recursos Naturales México, eD. F D. F.

Comisión Nacional del Agua (CONAGUA). 2010. Estadísticas del Agua en México, edición 2010. [online] URL: http://www. conagua.gob.mx/conagua07/publicaciones/publicaciones/ eam2010-16junio2010.pdf

Comisión Nacional del Agua (CONAGUA). 2011. Identificación de reservas potenciales de agua para el medio ambiente en México. Secretaría de Medio Ambiente y Recursos Naturales, Coyoacán, México, D.F.

Consejo de Cuenca del Río Bravo (CCRB). 2018. Sesiones del Consejo de Cuenca del Rio Bravo. [online] URL: https://www. cuencariobravo.org/sesiones

Cook, B. I., T. R. Ault, and J. E. Smerdon. 2015. Unprecedented 21 st century drought risk in the American Southwest and Central Plains. Science Advances 1(1):e1400082. https://doi.org/10.1126/ $\underline{\text { sciadv. } 1400082}$

Dean, D. J., and J. C. Schmidt. 2011. The role of feedback mechanisms in historic channel changes of the lower Rio Grande in the Big Bend region. Geomorphology 126(3):333-349. https:// doi.org/10.1016/j.geomorph.2010.03.009

Dean, D. J., and J. C. Schmidt. 2013. The geomorphic effectiveness of a large flood on the Rio Grande in the Big Bend region: insights on geomorphic controls and post-flood geomorphic response. Geomorphology 201:183-198. https://doi.org/10.1016/j. geomorph.2013.06.020

de la Lanza Espino, G., R. González Villela, I. D. González Mora, and S. Hernández Pulido. 2018. Caudal ecológico de ciertos ríos que descargan al Golfo de Mexico y al Pacífico Mexicano. Revista Iberoamericana Del Agua 5(1):3-15. https://doi.org/10.1080/23$\underline{863781.2018 .1442187}$

Desert Fish Habitat Partnership. 2016. Alamito Creek restoration. [online] URL: https://www.desertfhp.org/alamitocreek-restoration

Duran-Encalada, J. A., A. Paucar-Caceres, E. R. Bandala, and G. H. Wright. 2017. The impact of global climate change on water quantity and quality: a system dynamics approach to the USMexican transborder region. European Journal of Operational Research 256(2):567-581. https://doi.org/10.1016/j.ejor.2016.06.016

Earhart, J. 2012. A brief history of the Rio Grande International Study Center. [online] URL: https://rgisc.org/history/

Ebright, M. 1997. Land grants and lawsuits in northern New Mexico. New Mexico land grant series (USA).

Eichinger, W., J. Nichols, J. Prueger, L. Hipps, C. Neale, D. Cooper, and A. Bawazir. 2003. Lake evaporation estimation in arid 
environments. Hydroscience-Engineering Report No. 430, University of Iowa, Iowa City, Iowa, USA.

Elias, E. H., A. Rango, C. M. Steele, J. F. Mejia, and R. Smith. 2015. Assessing climate change impacts on water availability of snowmelt-dominated basins of the Upper Rio Grande basin. Journal of Hydrology: Regional Studies 3:525-546. https://doi. org/10.1016/j.ejrh.2015.04.004

Enríquez Coyro, E. 1976. El tratado entre México y los Estados Unidos de América sobre ríos internacionales. Comisión Nacional del Agua, Mexico City, Mexico.

Escobar-Arias, M. I., and G. B. Pasternack. 2010. A hydrogeomorphic dynamics approach to assess in-stream ecological functionality using the functional flows model, part 1 -model characteristics. River Research and Applications 26 (9):1103-1128. https://doi.org/10.1002/rra.1316

Everitt, B. 1993. Channel responses to declining flow on the Rio Grande between Ft. Quitman and Presidio, Texas. Geomorphology 6(3):225-242. https://doi.org/10.1016/0169-555X (93)90048-7

Fernald, A., S. Guldan, K. Boykin, A. Cibils, M. Gonzales, B. Hurd, S. Lopez, C. Ochoa, M. Ortiz, J. Rivera, S. Rodriguez, and C. Steele. 2015. Linked hydrologic and social systems that support resilience of traditional irrigation communities. Hydrology and Earth System Sciences 19(1):293-307.

Fleck, J. 2016. Water is for fighting over: and other myths about water in the West. Island Press.

Fort, D. D. 2000. Instream flows in New Mexico. SEL \& Associates 7(2):155-163.

Fuchs, E. H., K. C. Carroll, and J. P. King. 2018. Quantifying groundwater resilience through conjunctive use for irrigated agriculture in a constrained aquifer system. Journal of Hydrology 565:747-759. https://doi.org/10.1016/j.jhydrol.2018.08.003

Fullerton, W., and D. Batts. 2003. Framework for a restoration vision for the Rio Grande: hope for a living river. The Alliance for Rio Grande Heritage. World Wildlife Fund.

Gonzalez-Escorcia, Y. 2017. Determining the natural flow in the transboundary Rio Grande/Bravo Basin. Thesis. Instituto Politecnico Nacional \& University of California, Davis, Mexico City.

Gregory, A., R. R. Morrison, and M. Stone. 2018. Assessing the hydrogeomorphic effects of environmental flows using hydrodynamic modeling. Environmental Management 62 (2):352-364. https://doi.org/10.1007/s00267-018-1041-6

Groenfeldt, D., and J. J. Schmidt. 2013. Ethics and water governance. Ecology and Society 18(1):14. https://doi. org/10.5751/ES-04629-180114

Hargrove, W., D. Borrok, J. Heyman, C. Tweedie, and C. Ferregut. 2013. Water, climate, and social change in a fragile landscape. Ecosphere 4:1-13. https://doi.org/10.1890/ES12-00269.1

Hartwell, R., S. Kruse, and M. Buckley. 2016. San Juan-Chama headwaters return on investment study for the Rio Grande water fund. The Nature Conservancy, Santa Fe, New Mexico, USA.
Horgan, P. 1984. Great river: the Rio Grande in North American history. Fourth edition. Wesleyan University Press, Middletown, Connecticut, USA.

Horner, C. L. 2016. Middle Rio Grande habitat suitability criteria. Plan B technical report. Colorado State University, Fort Collins, Colorado, USA. [online] URL: https://www.engr.colostate.edu/ pierre/ce old/resume/Theses $\% 20$ and $\% 20$ Dissertations/Horner $\%$ 20Technical $\%$ 20Report.pdf

Hurd, B. H., and J. Coonrod. 2012. Hydro-economic consequences of climate change in the upper Rio Grande. Climate Research 53(2):103-118. https://doi.org/10.3354/cr01092

Ingol-Blanco, E., and D. C. McKinney. 2010. Transboundary climate change effects on the hydrologic regime in the Rio Conchos basin. Pages 60-68 in World Environmental and Water Resources Congress 2010: challenges of change. https://doi. org/10.1061/41114(371)8

International Boundary and Water Commission (IBWC). 2015. Rio Grande canalization project. International Boundary \& Water Commission, United States and Mexico, United States Section. [online] URL: https://www.ibwc.gov/EMD/canalization_eis. $\underline{\mathrm{html}}$

Kelly, M. E. 2002. Water management in the Binational Texas/ Mexico Rio Grande/Rio Bravo Basin. Yale School of Forestry and Environmental Studies Bulletin 115:134.

Kelly, M. E., and H. M. Arias Rojo. 2007. River habitat restoration in the Chihuahuan Desert: the Río Conchos and the forgotten river stretch of the Rio Grande. The U.S.-Mexican Border Environment: Transboundary Ecosystem Management: Southwest Consortium for Environmental Research and Policy (SCERP) Monograph 15.

King, J., and C. Brown. 2006. Environmental flows: striking the balance between development and resource protection. Ecology and Society 11(2):26. https://doi.org/10.5751/ES-01682-110226

Koch, J., J. R. Friedman, S. Paladino, S. Plassin, and K. Spencer. 2019. Conceptual modeling for improved understanding of the Rio Grande/Río Bravo socio-environmental system. SocioEnvironmental Systems Modelling 1(0). https://doi.org/10.18174/ sesmo.2019a16127

Lane, B. A., S. Sandoval-Solis, and E. C. Porse. 2015. Environmental flows in a human-dominated system: integrated water management strategies for the Rio Grande/Bravo basin. River Research and Applications 31(9):1053-1065. https://doi. org/10.1002/rra.2804

Lehner, F., E. R. Wahl, A. W. Wood, D. B. Blatchford, and D. Llewellyn. 2017. Assessing recent declines in Upper Rio Grande runoff efficiency from a paleoclimate perspective. Geophysical Research Letters 44(9):4124-4133. https://doi.org/10.1002/2017GL073253

Llewellyn, D., and S. Vaddey. 2013. West-wide climate risk assessment: Upper Rio Grande impact assessment. U.S. Department of the Interior, Bureau of Reclamation, Albuquerque, New Mexico, USA.

Mahoney, J. M., and S. B. Rood. 1998. Streamflow requirements for cottonwood seedling recruitment-an integrative model. Wetlands 18(4):634-645. 
Massey, D. S. 2016. The Mexico-US border in the American imagination. Proceedings of the American Philosophical Society 160(2):160-177.

Morett-Sánchez, J. C., and C. Cosío-Ruiz. 2017. Panorama de los ejidos y comunidades agrarias en México. Agricultura, Sociedad y Desarrollo 14(1):125-152.

Morrison, R. R., and M. C. Stone. 2014. Spatially implemented Bayesian network model to assess environmental impacts of water management. Water Resources Research 50(10):8107-8124.

Morrison, R. R., and M. C. Stone. 2015. Investigating environmental flows for riparian vegetation recruitment using system dynamics modelling. River Research and Applications 31 (4):485-496.

Moure-Eraso, R., M. Wilcox, L. Punnett, L. Copeland, and C. Levenstein. 1994. Back to the future: sweatshop conditions on the Mexico-U.S. border. I. Community health impact of maquiladora industrial activity. American Journal of Industrial Medicine 25 (3):311-324. https://doi.org/10.1002/ajim.4700250302

Mussetter, R. A., C. G. Wolff, M. R. Peters, D. B. Thomas, and D. Grochowski. 2004. Two-dimensional hydrodynamic modeling of the Rio Grande to support fishery habitat investigations. Pages 1-10 in G. Sehlke, D. F. Hayes, and D. K. Stevens, editors. Critical transitions in water and environmental resources management. World Water and Environmental Resources Congress 2004, June 27-July 1, 2004, Salt Lake City, Utah, USA. American Society of Civil Engineers.

National Research Council. 2005. The science of instream flows: a review of the Texas Instream Flow Program. National Academies Press, Washington, D.C., USA.

Nava, L. F. 2020. The Transboundary Paso del Norte Region. Pages 73-84 in E. de O. Vieira, S. Sandoval-Solis, V. de A. Pedrosa, and J. P. Ortiz-Partida, editors. Integrated water resource management: cases from Africa, Asia, Australia, Latin America and USA. Springer International Publishing. https://doi. org/10.1007/978-3-030-16565-9 7

Nava, L. F., C. Brown, K. Demeter, F. Lasserre, M. MilanésMurcia, S. Mumme, and S. Sandoval-Solis. 2016. Existing opportunities to adapt the Rio Grande/Bravo basin water resources allocation framework. Water 8(7):291. https://doi. org/10.3390/w8070291

Nava, L. F., and S. Sandoval-Solis. 2014. Multi-tiered governance of the Rio Grande/Bravo Basin: the fragmented water resources management model of the United States and Mexico. International Journal of Water Governance 2(1):85-106. https:// doi.org/10.7564/13-IJWG23

New Mexico Legislature. 2020. Severance tax bonds authorizations appropriations of proceeds. Section 34. Interstate Stream Commission Projects.

Office of the State Engineer (OSE). 2018. Strategic water reserve inventory.

Office of the State Engineer (OSE). 2020. Strategic water reserve reports. [online] URL: https://www.ose.state.nm.us/ISC/isc_SWR. php
Ortiz-Partida, J. P., B. A. Lane, and S. Sandoval-Solis. 2016. Economic effects of a reservoir re-operation policy in the Rio Grande/Bravo for integrated human and environmental water management. Journal of Hydrology: Regional Studies 8:130-144. https://doi.org/10.1016/j.ejrh.2016.08.004

Ostrom, E. 2009. A general framework for analyzing sustainability of social-ecological systems. Science 325 (5939):419-422. https://doi.org/10.1126/science.1172133

Paskus, L. 2015. The surprising gift from New Mexico's pueblos that might save the Rio Grande. [online] URL: https://www. audubon.org/news/the-surprising-gift-new-mexicos-pueblos-mightsave-rio-grande

Paulson, S., L. L. Gezon, A. Escobar, A. Gardner, M. Brodgen, J. Greenberg, H. Svarstad, M. Dove, A. Hornborg, C. Stevens, J. Heyman, F. Mackenzie, A. Ferguson, and W. Derman. 2004. Political ecology across spaces, scales, and social groups. S. Paulson and L. L. Gezon, editors. Rutgers University Press.

Perramond, E. P. 2016. Adjudicating hydrosocial territory in New Mexico. Water International 41(1):173-188. https://doi. org/10.1080/02508060.2016.1108442

Perramond, E. P. 2018. Unsettled waters: rights, law, and identity in the American West. University of California Press, Oakland California, USA.

Peterson, M. S. 2020. Nonprofit secures instream water rights to help cutthroat trout. [online] URL: https://www.taosnews.com/ la-vida/great-outdoors/nonprofit-secures-instream-water-rights-tohelp-cutthroat-trout/article b8e78b91-4364-58cf-8ee6-d8a521976590. $\underline{\mathrm{html}}$

Phillips, F. M., G. E. Hall, and M. E. Black. 2011. Reining in the Rio Grande: people, land, and water. University of New Mexico Press, Albuquerque, New Mexico, USA.

Plassin, S., J. Koch, S. Paladino, J. R. Friedman, K. Spencer, and K. B. Vaché. 2020. A socio-environmental geodatabase for integrative research in the transboundary Rio Grande/Río Bravo basin. Scientific Data 7(1):80. https://doi.org/10.1038/s41597-020-0410-1

Poff, N. L., J. D. Allan, M. B. Bain, J. R. Karr, K. L. Prestegaard, B. D. Richter, R. E. Sparks, and J. C. Stromberg. 1997. The natural flow regime. BioScience 47(11):769-784. https://doi.org/10.2307/1313099

Poff, N. L., and J. H. Matthews. 2013. Environmental flows in the Anthropocence: past progress and future prospects. Current Opinion in Environmental Sustainability 5(6):667-675. https:// doi.org/10.1016/j.cosust.2013.11.006

Poff, N. L., R. E. Tharme, and A. H. Arthington. 2017. Evolution of environmental flows assessment science, principles, and methodologies. Pages 203-236 in A. C. Horne, J. A. Webb, M. J. Stewardson, B. Richter, and M. Acreman, editors. Water for the environment. Academic Press. https://doi.org/10.1016/ B978-0-12-803907-6.00011-5

Porse, E. C., S. Sandoval-Solis, and B. A. Lane. 2015. Integrating environmental flows into multi-objective reservoir management for a transboundary, water-scarce river basin: Rio Grande/Bravo. Water Resources Management 29(8):2471-2484. 
Postel, S., B. Richter, and The Nature Conservancy. 2003. Rivers for life: managing water for people and nature. Island Press.

Pronatura Noreste, A. C. 2019. Informe Anual 2019. Pronatura Noreste. [online] URL: https://www.pronaturanoreste.org/ files/ ugd/d77584 3e9a9b2bc1eb41ed8225661d62a5f2ce.pdf

Rango, A. 2006. Snow: the real water supply for the Rio Grande basin. New Mexico Journal of Science 44:99-118.

Richter, B. D., D. Bartak, P. Caldwell, K. F. Davis, P. Debaere, A. Y. Hoekstra, T. Li, L. Marston, R. McManamay, M. M. Mekonnen, B. L. Ruddell, R. R. Rushforth, and T. J. Troy. 2020. Water scarcity and fish imperilment driven by beef production. Nature Sustainability 3(4):319-328. https://doi.org/10.1038/ S41893-020-0483-Z

Richter, B. D., M. M. Davis, C. Apse, and C. Konrad. 2012. A presumptive standard for environmental flow protection. River Research and Applications 28(8):1312-1321. https://doi. org/10.1002/rra.1511

Rio Grande, Rio Grande Estuary, and Lower Laguna Madre Basin and Bay Expert Science Team for the Lower Rio Grande Basin. 2012. Environmental flows recommendations report. Final submission to the Environmental Flows Advisory Group, Rio Grande, Rio Grande Estuary, and Lower Laguna Madre Basin and Bay Stakeholders Committee, and Texas Commission on Environmental Quality.

Roach, K. A. 2013. Texas water wars: how politics and scientific uncertainty influence environmental flow decision-making in the Lone Star state. Biodiversity and Conservation 22(3):545-565. https://doi.org/10.1007/s10531-013-0443-2

Roland, D. 2020. U.S. adds cameras at Mexico border despite drop in crossings. Fortune. [online] URL: https://fortune. com/2020/04/26/us-adds-cameras-at-mexico-border/

Rumsey, C. A., M. P. Miller, and G. A. Sexstone. 2020. Relating hydroclimatic change to streamflow, baseflow, and hydrologic partitioning in the Upper Rio Grande Basin, 1980 to 2015. Journal of Hydrology 584:124715. https://doi.org/10.1016/j. jhydrol.2020.124715

Samimi, M., A. Mirchi, N. T. Townsend, D. S. Gutzler, S. Daggubati, S. Ahn, Z. Sheng, D. Moriasi, A. Granados-Olivas, S. Alian, A. Mayer, and W. L. Hargrove. 2020. Climate change impacts on agricultural water availability in the Middle Rio Grande basin. Journal of the American Water Resources Association. https://doi.org/10.1111/1752-1688.12988

Sandoval-Solis, S., L. E. Garza-Díaz, and O. A. Leal-Nares. 2019. Estimación de Caudales Ecológicos para la Cuenca del Río Bravo. UC Davis Water Management Lab \& Pronatura noreste, Davis, California, USA.

Sandoval-Solis, S., and B. A. Lane. 2021. Rio Grande-Río Bravo environmental flows database. Data and tools. https://doi. org/10.4211/hs.76bd2b2e36aa4f23920b20e5a5accb2a

Sandoval-Solis, S., and D. C. McKinney. 2009. Hydrological feasibility of environmental flows in the Rio Grande/Bravo Basin. In World Environmental and Water Resources Congress, May 17-21, 2009, Kansas City, Missouri,USA. American Society of Civil Engineers. https://doi.org/10.1061/41036(342)497
Sandoval-Solis, S., and D. C. McKinney. 2011. Water planning and management for large scale river basins: case of study of the Rio Grande/Rio Bravo transboundary basin. Center for Research in Water Resources, University of Texas, Austin, Texas, USA.

Sandoval-Solis, S., and D. C. McKinney. 2014. Integrated water management for environmental flows in the Rio Grande. Journal of Water Resources Planning and Management 140(3):355-364.

Sandoval-Solis, S., D. C. McKinney, and D. P. Loucks. 2011. Sustainability Index for water resources planning and management. Journal of Water Resources Planning and Management 137(5):381-390. https://doi.org/10.1061/(ASCE) WR.1943-5452.0000134

Sayto-Corona, D., H. Silva-Hidalgo, S. Sandoval-Solis, C. Álvarez-Herrera, and E. Herrera-Peraza. 2017. Aproximación e impacto directo de ciclones tropicales a la cuenca del río Conchos, Chihuahua, México. Investigación y Ciencia 25(72):53-61. https://doi.org/10.33064/iycuaa201772222

Schmidt, J., B. Everitt, and G. Richard. 2003. Hydrology and geomorphology of the Rio Grande and implications for river rehabilitation. Aquatic Fauna of the Northern Chihuahuan Desert(46):25-45.

Schumacher, M., P. Durán-Díaz, A. K. Kurjenoja, E. GutiérrezJuárez, and D. A. González-Rivas. 2019. Evolution and collapse of Ejidos in Mexico - to what extent is communal land used for? Land 8:146. https://doi.org/10.3390/land8100146

Scurlock, D. 1998. From the Rio to the Sierra: an environmental history of the Middle Rio Grande Basin. U.S. Forest Service General Technical Report RMRS-GTR-5. https://doi.org/10.2737/ RMRS-GTR-5

Secretaría de Economía. 2012. Norma Mexicana NMX-AA-159SCFI-2012 that establishes the procedure for environmental flows determination in hydrological basins. [online] URL: https://www. gob.mx/cms/uploads/attachment/file/166834/NMX-AA-159-SCFI-2012. pdf

SEMARNAT. 2014. Decreto por el que se abrogan los acuerdos que se indican y se establece la reserva de aguas en las cuencas hidrológicas señaladas. Page Diario Oficial.

SEMARNAT. 2016. Decreto por el que se abrogan los acuerdos que se indican y se establece zona de reserva de auga para los usos doméstico y público urbano en la cuenca hidrológica Río Fuerte. Page Diario Oficial.

Sisto, N. P. 2009. Environmental flows for rivers and economic compensation for irrigators. Journal of Environmental Management 90(2):1236-1240. https://doi.org/10.1016/j. jenvman.2008.06.005

Sivapalan, M., H. H. G. Savenije, and G. Blöschl. 2011. Sociohydrology: a new science of people and water. Hydrological Processes 26(8):1270-1276. https://doi.org/10.1002/hyp.8426

Stanford, J. A., and J. V. Ward. 1993. An ecosystem perspective of alluvial rivers: connectivity and the hyporheic corridor. Journal of the North American Benthological Society 12(1):48-60. https:// doi.org/10.2307/1467685 
Stein, B. A., L. S. Kutner, and J. Adams, editors. 2000. Precious heritage: the status of biodiversity in the United States. Oxford University Press, Oxford, UK.

Stevens, S. 2013. New environmental water transaction program to begin on S. Rio Grande. Audubon. [online] URL: https://www. audubon.org/news/new-environmental-water-transaction-programbegin-srio-grande

Stone, M. C. 2008. Physical habitat model for the Rio Grande silvery minnow. Pages 1-10 in R. W. Babcock, Jr., and R. Walton, editors. World Environmental and Water Resources Congress 2008, May 12-16, 2008, Honolulu, Hawaii, USA. American Society of Civil Engineers.

Szeptycki, L. F., J. Forgie, E. Hook, K. Lorick, and P. Womble. 2015. Environmental water rights transfers: a review of state laws. Prepared by Water in the West for the National Fish and Wildlife Foundation, Washington, D.C., USA.

Tarlock, A. D., J. N. Corbridge, and D. H. Getches. 2002. Water resource management: a casebook in law and public policy. Foundation Press.

Tashjian, P. 2019. Audubon secures important water right that supports birds and people. Western Water News. [online] URL: https://www.audubon.org/news/audubon-secures-important-waterright-supports-birds-and-people?utm_source=ea\&utm_medium $=$ email\&utm campaign $=$ advocacy $\&$ emci $=5 \mathrm{a} 35 \mathrm{cdc} 0-750 \mathrm{~d}-$ ea11-828b-2818784d6d68\&emdi=ac28bf37-be0fea11-828b-2818784d6d68\&ceid $=74453$

Tennant, D. L. 1976. Instream flow regimens for fish, wildlife, recreation and related environmental resources. Fisheries 1 (4):6-10.

Texas Commission on Environmental Quality (TCEQ). 2008. Review of desk-top methods for establishing environmental flows in Texas rivers and streams. [online] URL: https://www.tceq. texas.gov/assets/public/permitting/watersupply/water rights/ txefsacdesktop.pdf

Texas Commission on Environmental Quality (TCEQ). 2012. Rio Grande, Rio Grande Estuary, and Lower Laguna Madre Basin and Bay Area Stakeholder Committee and Expert Science Team. [online] URL: https://www.tceq.texas.gov/permitting/water rights/ wr technical-resources/eflows/rio-grande-rio-grande-estuary-andlower-laguna-madre

Texas Commission on Environmental Quality (TCEQ). 2020. Basin and bay stakeholder committees and expert science teams. [online] URL: https://www.tceq.texas.gov/permitting/water_rights/ wr technical-resources/eflows/stakeholder-committees-and-scienceteams

Texas Water Development Board (TWDB). 2006. Texas Water Bank Trust. [online] URL: http://www.twdb.texas.gov/waterplanning/ waterbank/trust/index.asp

Texas Water Development Board (TWDB). 2020. Statewide environmental flows (SB3). [online] URL: https://www.twdb. texas.gov/surfacewater/flows/environmental/index.asp

Tharme, R. E. 1996. Review of international methodologies for the quantification of the instream flow requirements of rivers. Water Law review: final report for policy development, South
African Department of Water Affairs and Forestry. University of Cape Town, Freshwater Research Unit, Pretoria, South Africa.

Tharme, R. E. 2003. A global perspective on environmental flow assessment: emerging trends in the development and application of environmental flow methodologies for rivers. River Research and Applications 19(5-6):397-441. https://doi.org/10.1002/ $\underline{\operatorname{rra} .736}$

The Nature Conservancy (TNC). 2020. Sustainable Rivers Program. [online] URL: https://www.nature.org/en-us/what-wedo/our-priorities/protect-water-and-land/land-and-water-stories/ sustainable-rivers-project/

Tidwell, V. C., H. D. Passell, S. H. Conrad, and R. P. Thomas. 2004. System dynamics modeling for community-based water planning: application to the Middle Rio Grande. Aquatic Sciences 66(4):357-372. https://doi.org/10.1007/s00027-004-0722-9

Townsend, N. T., and D. S. Gutzler. 2020. Adaptation of climate model projections of streamflow to account for upstream anthropogenic impairments. Journal of the American Water Resources Association 56(4):586-598. https://doi. org/10.1111/1752-1688.12851

Trungale Engineering and Science. 2012. Instream flow-habitat relationships in the Upper Rio Grande River Basin. Austin, Texas, USA. http://www.cpwac.org/studyfile/upper rio grande.pdf

Udall, T. 1998. Opinion No. 98-01: Legal protection to instream flows' for recreational, fish or wildlife, or ecological purposes. State of New Mexico Office of the Attorney General.

United States Fish and Wildlife Service (USFWS). 2001. Programmatic biological opinion on water management in the Middle Rio Grande, New Mexico.

United States Fish and Wildlife Service (USFWS). 2003. Biological and conference opinions on the effects of actions associated with the programmatic biological assessment of Bureau of Reclamation's water and river maintenance operations, Army Corps of Engineers flood control operation, and related non-federal actions on the Middle Rio Grande, New Mexico. New Mexico Ecological Services Field Office, Albuquerque, New Mexico, USA

United States Fish and Wildlife Service (USFWS). 2010. Rio Grande silvery minnow recovery plan (Hybognathys amarus). First revision. Albuquerque, New Mexico, USA.

United States Geological Survey. 2010. Estimated use of water in the United States. County-level data for 2010. National Water Information System.

Upper Rio Grande Basin and Bay Expert Science Team. 2012. Environmental flows recommendations report. Final submission to the Environmental Flows Advisory Group, Rio Grande Basin and Bay Area Stakeholders Committee and Texas Commission on Environmental Quality.

Utton, A. E. 1999. Coping with drought on an international river under stress: the case of the Rio Grande/Rio Bravo. Natural Resources Journal 39:27.

Vidales-Contreras, J. A., J. F. Pissani-Zuñiga, H. RodríguezFuentes, E. O. Sáenz, J. Aranda-Ruiz, and A. I. Luna-Maldonado. 
2014. Regimens of ecological flow rates on the Pilon River. Journal of Experimental Biology and Agricultural Sciences 2 (4):380-386.

Ward, F. A., and J. F. Booker. 2006. Economic impacts of instream flow protection for the Rio Grande silvery minnow in the Rio Grande basin. Reviews in Fisheries Science 14(1-2):187-202.

Ward, F. A., J. F. Booker, and A. M. Michelsen. 2006. Integrated economic, hydrologic, and institutional analysis of policy responses to mitigate drought impacts in Rio Grande Basin. Journal of Water Resources Planning and Management 132 (6):488-502. https://doi.org/10.1061/(ASCE)0733-9496(2006)132:6 $\underline{(488)}$

Water Utility Authority. 2016. Water 2120: securing our water future. Albuquerque Bernalillo County Water Utility Authority, Albuquerque, New Mexico, USA.

Wong, C., C. Williams, J. Pittock, U. Collier, and P. Schelle. 2007. World's top 10 rivers at risk. World Wildlife Fund International, Gland, Switzerland.

World Wildlife Fund (WWF). 2006. Conclusions from the Building Block Method specialist work session Rio Conchos. February 27 to March 1, 2006.

World Wildlife Fund (WWF). 2019. Programa de reservas de agua: una estrategia de adaptación ante el cambio climático. [online] URL: http://awsassets.panda.org/downloads/

fs_reservas_de agua esp_2.pdf

Wozniak, F. E. 1998. Irrigation in the Rio Grande Valley, New Mexico: a study and annotated bibliography of the development of irrigation systems. U.S. Forest Service Proceedings RMRSP-2.

Yarnell, S. M., G. E. Petts, J. C. Schmidt, A. A. Whipple, E. E. Beller, C. N. Dahm, P. Goodwin, and J. H. Viers. 2015. Functional flows in modified riverscapes: hydrographs, habitats and opportunities. BioScience 65(10):963-972. https://doi.org/10.1093/ biosci/biv102

Yarnell, S. M., E. D. Stein, J. A. Webb, T. Grantham, R. A. Lusardi, J. Zimmerman, R. A. Peek, B. A. Lane, J. Howard, and S. Sandoval-Solis. 2020. A functional flows approach to selecting ecologically relevant flow metrics for environmental flow applications. River Research and Applications 36(2):318-324. https://doi.org/10.1002/rra.3575

Young, M. K. 1995. Conservation assessment for inland cutthroat trout. U.S. Forest Service General Technical Report RM-256. https://doi.org/10.2737/RM-GTR-256

Zepeda-Martínez, L. M. 2012. Determinación de caudales ambientales para ríos de la cuenca del río San Juan (México). Thesis. Universidad Autónoma De Nuevo León. Facultad De Ingeniería Civil. 
Appendix 1. Summary table of projects where environmental flows have been implemented.

\begin{tabular}{|c|c|c|c|c|c|}
\hline $\begin{array}{l}\text { Related } \\
\text { Section }\end{array}$ & Strategy & Geographic extent & When & $\begin{array}{l}\text { Key actors and } \\
\text { institutions }\end{array}$ & Reference \\
\hline$A$ & $\begin{array}{l}\text { Representative for } \\
\text { environmental flows added to } \\
\text { multi-state, basin planning } \\
\text { council }\end{array}$ & $\begin{array}{l}\text { Area of the RGB } \\
\text { basin located in } \\
\text { Mexico (Durango, } \\
\text { Chihuahua, Nuevo } \\
\text { León, Coahuila, } \\
\text { Tamaulipas) }\end{array}$ & 2017 & $\begin{array}{l}\text { Rio Bravo Basin } \\
\text { Council and } \\
\text { Pronatura Noreste }\end{array}$ & $\begin{array}{l}\text { (CCRB } \\
2018 \mathrm{a})\end{array}$ \\
\hline B. 1 & $\begin{array}{l}\text { 5-year lease of agricultural } \\
\text { water rights for environmental } \\
\text { flows }\end{array}$ & $\begin{array}{l}\text { New Mexico, U.S.: } \\
\text { Rio Gallinas, } \\
\text { upstream of the } \\
\text { confluence with Rio } \\
\text { Chama, New Mexico }\end{array}$ & 2019 & $\begin{array}{l}\text { NMOSE, Audubon } \\
\text { New Mexico, and } \\
\text { Farmers }\end{array}$ & $\begin{array}{l}\text { (Tashjian } \\
2019, \\
\text { Chamberlain } \\
\text { 2019) }\end{array}$ \\
\hline B.2 & $\begin{array}{l}\text { Leasing of agricultural water } \\
\text { rights for environmental flows } \\
\text { to preserve native trout }\end{array}$ & $\begin{array}{l}\text { Gallinas creek } \\
\text { (tributary of the } \\
\text { Pecos River) in } \\
\text { northern New Mexico }\end{array}$ & 2019 & $\begin{array}{l}\text { Trout Unlimited, } \\
\text { private landowner }\end{array}$ & $\begin{array}{l}\text { (Peterson } \\
\text { 2020) }\end{array}$ \\
\hline B.3 & $\begin{array}{l}\text { Strategic water reserve that } \\
\text { provides funding to lease or } \\
\text { purchase environmental flow } \\
\text { water rights in the state of } \\
\text { New Mexico }\end{array}$ & $\begin{array}{l}\text { New Mexico, U.S.: } \\
\text { the RGB above } \\
\text { Elephant Butte and } \\
\text { the Pecos River }\end{array}$ & $\begin{array}{l}\text { Since } \\
2005\end{array}$ & $\begin{array}{l}\text { New Mexico } \\
\text { Legislature }\end{array}$ & (OSE 2020) \\
\hline C. 1 & $\begin{array}{l}\text { Voluntary releases of unused } \\
\text { water in reservoirs for } \\
\text { environmental flow }\end{array}$ & $\begin{array}{l}\text { Rio Chama } \\
\text { downstream El Vado } \\
\text { Reservoir (New } \\
\text { Mexico) }\end{array}$ & 2016 & $\begin{array}{l}\text { NM Audubon, } \\
\text { Sandia Pueblo }\end{array}$ & $\begin{array}{l}\text { (Paskus } \\
2015 \text { ) }\end{array}$ \\
\hline C.2 & $\begin{array}{l}\text { Voluntary releases of water in } \\
\text { reservoirs for environmental } \\
\text { flow }\end{array}$ & $\begin{array}{l}\text { 34-mile reach of the } \\
\text { Rio Grande } \\
\text { downstream of Isleta } \\
\text { Diversion Dam and } \\
\text { through isleta } \\
\text { Pueblo, Los Lunas, } \\
\text { and Belen (New } \\
\text { Mexico) }\end{array}$ & 2018 & $\begin{array}{l}\text { NM Audubon, } \\
\text { Middle Rio Grande } \\
\text { Conservancy } \\
\text { District, Bureau of } \\
\text { Reclamation, } \\
\text { Pueblo of Isleta, } \\
\text { Albuquerque } \\
\text { Bernalillo County } \\
\text { Water Utility } \\
\text { Authority }\end{array}$ & $\begin{array}{l}\text { (Audubon } \\
\text { 2018) }\end{array}$ \\
\hline D. 1 & $\begin{array}{l}\text { Municipal ordinance to } \\
\text { provide environmental flows }\end{array}$ & $\begin{array}{l}\text { Santa Fe City and } \\
\text { Santa Fe river }\end{array}$ & 2012 & $\begin{array}{l}\text { City of Santa Fe } \\
\text { Environmental } \\
\text { advocacy groups } \\
\text { (e.g. Santa Fe } \\
\text { Watershed } \\
\text { Association) }\end{array}$ & $\begin{array}{l}\text { (City of Santa } \\
\text { Fe 2013) }\end{array}$ \\
\hline D.2 & $\begin{array}{l}\text { Municipal ordinances to } \\
\text { ensure environmental flows } \\
\text { for fishway pass and } \\
\text { sediment movement }\end{array}$ & $\begin{array}{l}\text { Albuquerque City } \\
\text { and RGB mainstem }\end{array}$ & 2016 & City of Albuquerque & $\begin{array}{l}\text { (Water Utility } \\
\text { Authority } \\
\text { 2016) }\end{array}$ \\
\hline
\end{tabular}




\begin{tabular}{|c|l|l|l|l|l|}
\hline E & $\begin{array}{l}\text { First environmental water } \\
\text { right in Mexico }\end{array}$ & $\begin{array}{l}\text { Coahuila, México: } \\
\text { Cuatro Ciénegas }\end{array}$ & $\begin{array}{l}\text { 2014- } \\
\text { present }\end{array}$ & $\begin{array}{l}\text { CONAGUA, } \\
\text { Pronatura Noreste }\end{array}$ & $\begin{array}{l}\text { (Pronatura } \\
\text { Noreste } \\
\text { 2019) }\end{array}$ \\
\hline F & $\begin{array}{l}\text { Cross-sectoral,cross- } \\
\text { jurisdictional and cross- } \\
\text { boundary collaboration in } \\
\text { forest management for water } \\
\text { quality and flow: the Rio } \\
\text { Grande Water Fund }\end{array}$ & $\begin{array}{l}\text { Rio Blanco, Rio } \\
\text { Navajo in the } \\
\text { Colorado River Basin } \\
\text { and Rio Chama in } \\
\text { the RGB basin }\end{array}$ & 2016 & $\begin{array}{l}\text { The Nature } \\
\text { Conservancy, state } \\
\text { agencies, local } \\
\text { municipalities, } \\
\text { community-level } \\
\text { donors across NM }\end{array}$ & $\begin{array}{l}\text { (Hartwell et } \\
\text { al. 2016) }\end{array}$ \\
\hline G. & $\begin{array}{l}\text { Adapting irrigation district } \\
\text { policy to accommodate river } \\
\text { restoration with agricultural } \\
\text { water rights }\end{array}$ & $\begin{array}{l}\text { Southern New } \\
\text { Mexico: Elephant } \\
\text { Butte reservoir to } \\
\text { Texas border }\end{array}$ & 2013 & $\begin{array}{l}\text { Elephant Butte } \\
\text { Irrigation District, } \\
\text { International } \\
\text { Boundary and } \\
\text { Water Commission, } \\
\text { Audubon New } \\
\text { Mexico, US Fish } \\
\text { and Wildlife Service }\end{array}$ & $\begin{array}{l}\text { (Stevens } \\
2013, \text { IBWC } \\
\text { IB15, n.d.) }\end{array}$ \\
\hline H & $\begin{array}{l}\text { Scientist advisory groups } \\
\text { determining environmental } \\
\text { flows }\end{array}$ & $\begin{array}{l}\text { Rio Grande } \\
\text { mainstem from } \\
\text { Presidio to Amistad } \\
\text { dam, from Falcon } \\
\text { dam to the estuary } \\
\text { and the Laguna } \\
\text { Madre (Texas) }\end{array}$ & 2011 & $\begin{array}{l}\text { Basin and Bay } \\
\text { Area Expert } \\
\text { Science Teams, } \\
\text { Basin and Bay } \\
\text { Area Stakeholder } \\
\text { Committee }\end{array}$ & (TCEQ 2012) \\
\hline I & $\begin{array}{l}\text { Nongovernmental } \\
\text { organizations promoting } \\
\text { socio-ecologically based land } \\
\text { and water management for } \\
\text { conservation }\end{array}$ & $\begin{array}{l}\text { Alamito Creek and } \\
\text { Matonoso Creek } \\
\text { (Texas) }\end{array}$ & 2003 & $\begin{array}{l}\text { Dixon Water } \\
\text { Foundation and } \\
\text { Trans Pecos Water } \\
\text { and Land Trust } \\
\text { (TPWT) }\end{array}$ & $\begin{array}{l}\text { (Desert Fish } \\
\text { Habitat } \\
\text { Partnership } \\
2016)\end{array}$ \\
\hline
\end{tabular}


Appendix 2. Future research.

There are significant research gaps on how environmental flows interact with agriculture and with landowners/managers. It is important to differentiate among the different kinds and purposes of farming systems in the basin, and how they interact with river ecosystems, hydrology, climate change, and socio-political and economic dynamics. Farmers' and land managers' knowledge must be included to consider their needs, objectives, and constraints, and how environmental flows do or do not align with these, in both the short- and long-terms. Qualitative and quantitative research in collaboration with the agricultural sector can help identify benefits, risks, and impacts to agriculture, including identifying alternatives that minimize food-security risks (cf. Richter et al. 2020). Research must identify policy, technical, economic, socio-cultural, organizational, and other strategies that support benefits and mitigate negative impacts. This work must remain honest about where and when an increased investment in environmental flows might be costly to agriculture or other human consumptive uses of water in the RGB, in order to be proactive about possible solutions (e.g., government support measures to minimize these impacts). This is an important future research line that can bring the environmental and agricultural sectors together. 